\title{
Post-Caledonian brittle deformation in the Bergen area, West Norway: results from K-Ar illite fault gouge dating
}

\author{
Anna K. Ksienzyk1, Klaus Wemmer², Joachim Jacobs 1,3, Haakon Fossen 1,4, \\ Anna C. Schomberg ${ }^{2}$, Annette Süssenberger ${ }^{5}$, N. Keno Lünsdorf ${ }^{2}$ \& Eivind Bastesen ${ }^{6}$ \\ ${ }^{1}$ Department of Earth Science, University of Bergen, P.O. Box 7803, 5020 Bergen, Norway. \\ ${ }^{2}$ Geoscience Centre, University of Göttingen, Goldschmidtstraße 3, 37077 Göttingen, Germany. \\ ${ }^{3}$ Norwegian Polar Institute, Fram Center, P.O. Box 6606 Langnes, 9296 Tromsø, Norway. \\ ${ }^{4}$ Natural History Collections, University Museum of Bergen, University of Bergen, P.O. Box 7800, 5020 Bergen, Norway. \\ ${ }^{5}$ Earth and Environmental Sciences, Université de Genève, 13 Rue des Maraîchers, 1205 Genève, Switzerland. \\ ${ }^{6}$ Uni Research CIPR, P.O. Box 7810, 5020 Bergen, Norway. \\ E-mail corresponding author (Anna K. Ksienzyk): anna.ksienzyk@uib.no
}

\begin{abstract}
Post-Caledonian extension during orogenic collapse and Mesozoic rifting in the West Norway-northern North Sea region was accommodated by the formation and repeated reactivation of ductile shear zones and brittle faults. Offshore, the Late Palaeozoic-Mesozoic rift history is relatively well known; extension occurred mainly during two rift phases in the Permo-Triassic (Phase 1) and Mid-Late Jurassic (Phase 2). Normal faults in the northern North Sea, e.g., on the Horda Platform, in the East Shetland Basin and in the Viking Graben, were initiated or reactivated during both rift phases. Onshore, on the other hand, information on periods of tectonic activity is sparse as faults in crystalline basement rocks are difficult to date. KAr dating of illite that grows synkinematically in fine-grained fault rocks (gouge) can greatly help to determine the time of fault activity, and we apply the method to nine faults from the Bergen area. The $\mathrm{K}-\mathrm{Ar}$ ages are complemented with X-ray diffraction analyses to determine the mineralogy, illite crystallinity and polytype composition of the samples. Based on these new data, four periods of onshore fault activity could be defined: (1) the earliest growth of fault-related illite in the Late Devonian-Early Carboniferous (>340 Ma) marks the waning stages of orogenic collapse; (2) widespread latest Carboniferous-Mid Permian (305-270 Ma) fault activity is interpreted as the onset of Phase 1 rifting, contemporaneous with rift-related volcanism in the central North Sea and Oslo Rift; (3) a Late Triassic-Early Jurassic (215-180 Ma) period of onshore fault activity postdates Phase 1 rifting and predates Phase 2 rifting and is currently poorly documented in offshore areas; and (4) Early Cretaceous (120-110 Ma) fault reactivation can be linked either to late Phase 2 North Sea rifting or to North Atlantic rifting.
\end{abstract}

Keywords: fault gouge, illite, $\mathrm{K}-$ Ar dating, geochronology, rifting

Electronic Supplement 1: Field descriptions of faults and host rocks.

Electronic Supplement 2: Analytical details.

Electronic Supplement 3: Polytype quantification.

Received 1. April 2016 / Accepted 18. October 2016 / Published online 8. December 2016

\section{Introduction}

The Caledonian Orogeny was the last of several orogenies that shaped West Norway, and during its final Silurian to Early Devonian Scandian phase, Baltica and Avalonia collided with Laurentia (e.g., Cocks \& Torsvik, 2006; Gee et al., 2008). Large allochthonous nappes were thrust hundreds of kilometres onto Baltica as far eastwards as the Oslo region, and the Baltican basement was driven underneath Laurentia to depths of up to $200 \mathrm{~km}$ (van Roermund \& Drury, 1998; van Roermund, 2009). The mountain range that resulted from the collision rivalled the modern-day Himalayas in length and height (Gee et

Ksienzyk, A.K., Wemmer, K., Jacobs, J., Fossen, H., Schomberg, A.C., Süssenberger, A., Lünsdorf, N.K. \& Bastesen, E. 2016: Post-Caledonian brittle deformation in the Bergen area, West Norway: results from K-Ar illite fault gouge dating. Norwegian Journal of Geology 96, 275-299.

http://dx.doi.org/10.17850/njg96-3-06. 
al., 2010; Streule et al., 2010). However, the Caledonian Orogen was topographically unstable, and as soon as contraction stopped, extensional tectonics took over and have repeatedly been dismembering the mountains and thinning the crust over the last 400 million years (Andersen, 1998; Fossen, 2000, 2010; Fossen et al., 2014). Ductile shear zones and later brittle faults have played a crucial role during the decay of the mountain range and later rifting of the North Sea and North Atlantic (Fossen, 2000; Fossen et al., 2016). Large fault systems that developed during orogenic collapse, for example the Hardangerfjord Shear Zone (HSZ in Fig. 1; Fossen \& Hurich, 2005), still influence the landscape of western Norway today. While the high-temperature processes of the Caledonian Orogeny and early orogenic collapse can be dated by a variety of geochronological methods such as $\mathrm{U}-\mathrm{Pb}, \mathrm{Lu}-\mathrm{Hf}, \mathrm{Sm}-\mathrm{Nd}, \mathrm{K}-\mathrm{Ar}$ and $\mathrm{Ar}-$ Ar geochronology (e.g., Fossen \& Dunlap, 1998; Bingen et al., 2001; Fossen \& Dunlap, 2006; Walsh et al., 2007; Bingen \& Solli, 2009; Smit et al., 2010), the multiphase Late Palaeozoic-Mesozoic rift history of West Norway is more difficult to constrain. The main rift structures are located offshore, but the tectonic evolution of onshore and offshore areas is strongly linked (e.g., Fossen et al., 2016) and needs to be considered as a cohesive system in order to understand western Norway's evolution from a high-standing Caledonian mountain range to the elevated rifted margin of today.

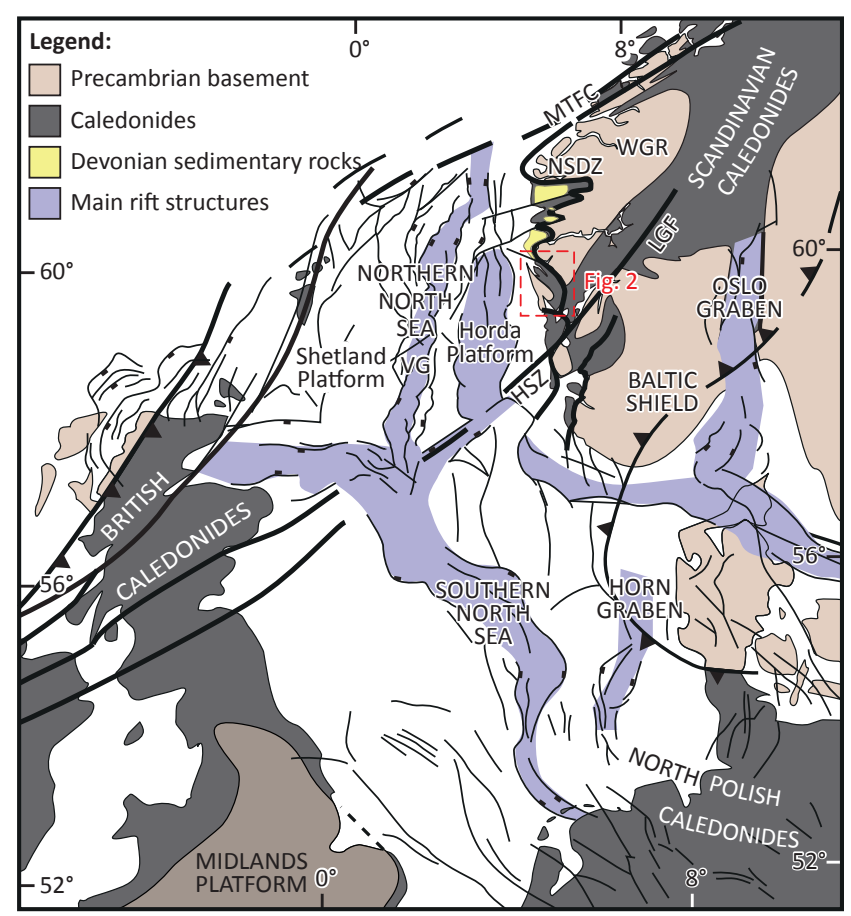

Figure 1. Overview map over the southern Scandinavian and British Caledonides and the North Sea region, showing main rift structures and fault systems (modified from Fossen et al., 2016). Abbreviations: HSZ - Hardangerfjord Shear Zone, LGF - Lordal-Gjende Fault, MTFC - Møre-Trøndelag Fault Complex, NSDZ - Nordfjord-Sogn Detachment Zone, VG - Viking Graben, WGR - Western Gneiss Region.
In the northern North Sea, extensive hydrocarbon exploration has resulted in a thorough knowledge of the post-Caledonian tectonic evolution of the offshore region. The large sedimentary basins of the northern North Sea (Fig. 1) formed during a two-stage rift history, with an initial, wide Permo-Triassic rifting followed by a Mid-Late Jurassic rift phase that was focused mainly in the Viking Graben (e.g., Badley et al., 1988; Gabrielsen et al., 1990; Steel \& Ryseth, 1990; Færseth, 1996; Bell et al., 2014). In the Early Cretaceous, rifting was abandoned in most of the North Sea and instead became focused along the future North Atlantic, which experienced important rift stages in the Early Cretaceous, Mid Cretaceous and Palaeocene, culminating in continental breakup in the Early Eocene (Doré et al., 1999). An abundance of highquality seismic data allows the mapping of offshore fault systems in detail. Owing to the well-preserved sedimentary record, movement along these faults can be constrained stratigraphically, showing many faults to have been active during both rift phases (e.g., Bell et al., 2014).

Onshore, on the other hand, the post-Caledonian geological record is sparse. Western Norway is dissected by numerous faults (Figs. 1,2), but these structures are generally hosted in crystalline basement rocks. Without stratigraphic markers, it can be difficult to determine the amount and even the sense of offset, let alone the time of fault activity. Thermochronological studies help to reconstruct cooling histories of basement rocks and reveal periods of uplift and erosion or sedimentary burial (Andriessen \& Bos, 1986; Rohrman et al., 1995; Leighton, 2007; Johannessen et al., 2013; Ksienzyk et al., 2014). Several of these studies (Leighton, 2007; Johannessen et al., 2013; Ksienzyk et al., 2014) show that the distribution of fission track and (U-Th)-He ages is strongly tectonically controlled and fault-bound blocks have distinct cooling histories from their neighbours, highlighting the significance of active fault tectonics throughout the Mesozoic. Nonetheless, only two faults with cohesive fault rocks (the Dalsfjord and LærdalGjende faults) have been dated to be of Permian and Late Jurassic-Early Cretaceous age (Torsvik et al., 1992; Eide et al., 1997; Andersen et al., 1999). Faults with incohesive fault rocks are generally assumed to be the youngest tectonic features, but have for a long time been difficult to date. Especially the fine-grained nature of synkinematically grown minerals and incomplete isotopic resetting of inherited minerals in low-temperature shallow crustal fault rocks have presented a challenge to the absolute dating approach. However, since Lyons \& Snellenburg (1971) successfully applied K-Ar dating to fine fractions separated from fault gouge and thereby demonstrated the potential of the method, both $\mathrm{K}-\mathrm{Ar}$ and Ar-Ar dating have been used to investigate faults from as young as Neogene (Haines \& van der Pluijm, 2010; Zwingmann et al., 2010b) to as old as Neoproterozoic (Viola et al., 2013). In this contribution we apply KAr geochronology of illite-bearing fine fractions from incohesive fault rocks to date faults from the Bergen area 


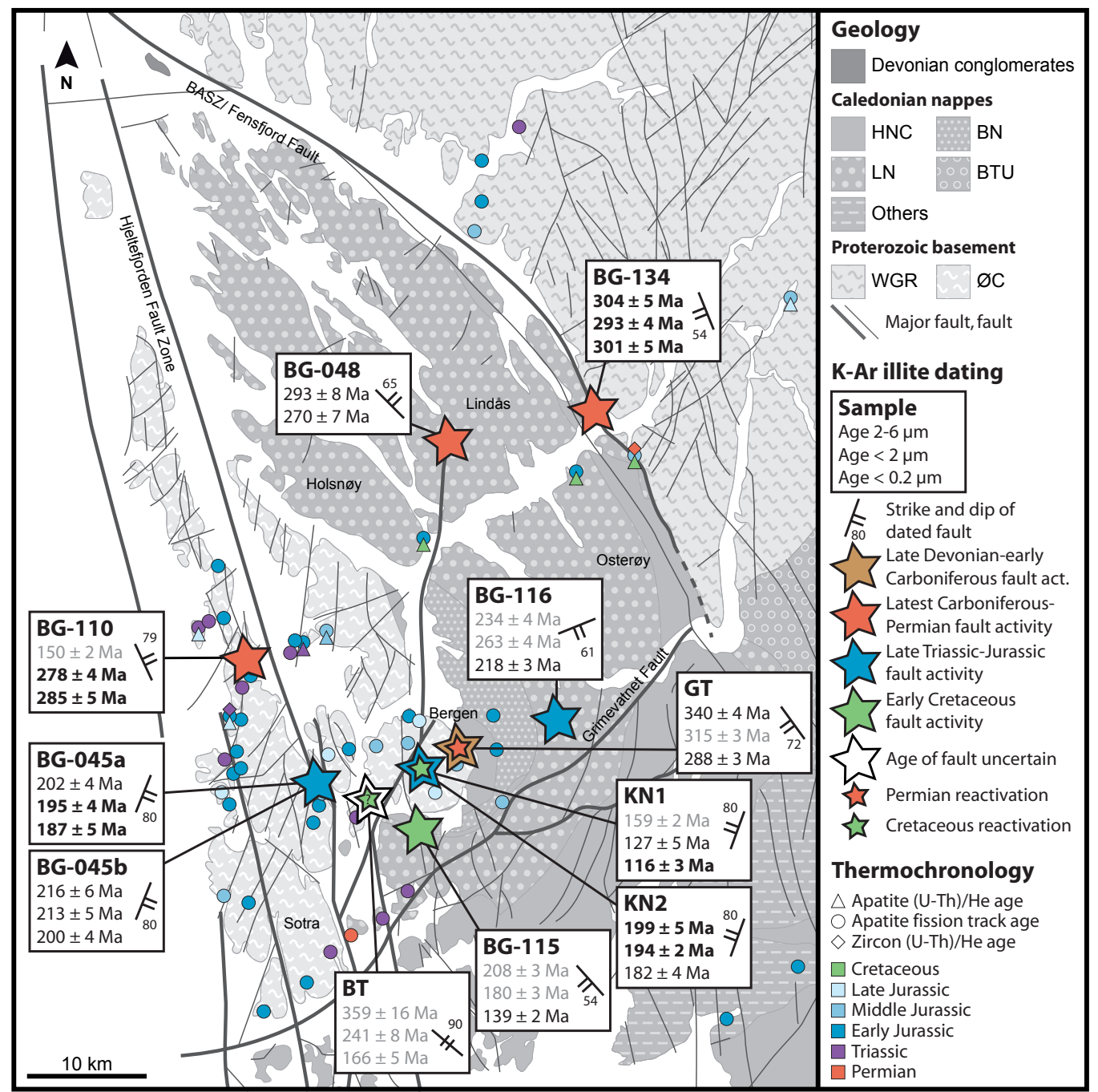

Figure 2. Simplified geological map showing the locations, orientations and fine-fraction ages of dated faults (this study), as well as other thermochronological data from the study area (Ksienzyk et al., 2014). Ages in black bold letters are interpreted to date fault activity; ages in black regular letters are close to fault activity but affected by minor mixing with older or younger illite/muscovite; grey ages are interpreted as mixed or otherwise unexplained ages with little geological significance. Abbreviations: BASZ - Bergen Arc Shear Zone, BN - Blåmanen Nappe, BTU - Bergsdalen Tectonic Unit; HNC - Hardangerfjord Nappe Complex, LN - Lindås Nappe, WGR - Western Gneiss Region, ØC - Øygarden Complex.

with the aim to establish the main periods of onshore fault activity and investigate the temporal relationships between onshore and offshore tectonics.

\section{Geological background}

The area around Bergen is part of the Scandinavian Caledonides of West Norway (Fig. 1). Two main tectonic units can be distinguished, the Precambrian basement (Øygarden Complex and Western Gneiss Region) and a series of Caledonian nappes (Fig. 2). The Øygarden Complex and Western Gneiss Region comprise predominantly Proterozoic gneisses and mafic to felsic plutonic rocks with minor metamorphosed supracrustal successions (Ragnhildstveit \& Helliksen, 1997; Fossen
\& Ragnhildstveit, 2008). Both the Øygarden Complex and the western part of the Western Gneiss Region are characterised by pervasive Palaeozoic ductile deformation, much of which is related to west-vergent post-collisional extensional deformation (Fossen, 1993; Milnes et al., 1997). The Caledonian nappe stack includes mainly the Lindås Nappe, Blåmanen Nappe and Hardangerfjord Nappe Complex. The Lindås Nappe is composed of a Mesoproterozoic-Neoproterozoic anorthosite-mangerite-charnockite-granite suite and granulite-facies gneisses of unknown Proterozoic age; both experienced Caledonian metamorphism, locally up to eclogite-facies conditions (e.g., Austrheim, 1987; Kühn et al., 2002). The Blåmanen Nappe comprises Proterozoic plutonic rocks and a MesoproterozoicNeoproterozoic sedimentary cover and has a mainly Caledonian metamorphic overprint (Fossen, 1988; Fossen \& Ragnhildstveit, 2008). The Hardangerfjord 
Nappe Complex forms the Major and Minor Bergen Arcs in the study area, which are predominantly composed of ophiolitic rocks of Early Ordovician age with minor Cambro-Silurian metasedimentary rocks and Proterozoic gneisses, all metamorphosed and juxtaposed during the Caledonian Orogeny (Ragnhildstveit \& Helliksen, 1997; Fossen \& Dunlap, 2006; Fossen \& Ragnhildstveit, 2008).

Late Silurian-Early Devonian Caledonian contractional deformation was closely followed by extension and orogenic collapse. The onset of extensional deformation in the Early Devonian (between 408 and $402 \mathrm{Ma}$ ) was marked by a backsliding of the Caledonian thrust nappes along the main basal décollement zone (Mode I extension; Fossen \& Dunlap, 1998; Fossen, 2000). The low angle of the décollement zone soon made sliding unfeasible, and further extension was taken up by newly formed crustal-scale shear zones (Mode II extension; Fossen, 2000), including the Nordfjord-Sogn Detachment Zone (NSDZ in Fig. 1; Andersen \& Jamtveit, 1990; Andersen et al., 1999) and the Hardangerfjord Shear Zone (HSZ in Fig. 1; Fossen \& Hurich, 2005). In the study area, Mode II extension is represented by the Bergen Arc Shear Zone (BASZ in Fig. 2), which is an arcuate, generally $\mathrm{W}$-dipping structure that separates the Lindås Nappe and Major Bergen Arc from the Western Gneiss Region and Bergsdalen Tectonic Unit to the north and east (Wennberg et al., 1998).

During the Devonian, cooling of the crust through the ductile-brittle transition allowed for the development of steep brittle faults (Mode III extension; Fossen, 2000). Titanites that grew in fault-related fractures have been dated by $\mathrm{U}-\mathrm{Pb}$ geochronology to be $396 \mathrm{Ma}$ (Larsen et al., 2003), which marks the onset of brittle deformation in the study area. Based on field relationships and characteristic mineralisation, Larsen et al. (2003) divided brittle faults in the Øygarden Complex into NE-SW-striking Set I fractures and mainly NNW-SSEstriking Set II fractures. Set I fractures are associated with epidote (+ quartz, chlorite, titanite and secondary calcite) mineralisation and show marked K-feldspar alteration in the host rock. They formed during the Mid to Late Devonian under NW-SE extension (Larsen et al., 2003). Set II fractures show mainly calcite (+ quartz and chlorite) mineralisation and formed prior to or during Permian dyke intrusion under E-W extension (Fossen, 1998; Valle et al., 2002; Larsen et al., 2003). Also many of the Mode II extensional ductile shear zones were reactivated as brittle faults during the Late Palaeozoic and Mesozoic, e.g., the Dalsfjord Fault (reactivating the Nordfjord-Sogn Detachment Zone; Torsvik et al., 1992; Eide et al., 1997), the Lærdal-Gjende Fault (reactivating the Hardangerfjord Shear Zone; Andersen et al., 1999) and the Fensfjord Fault (reactivating the Bergen Arc Shear Zone; Wennberg \& Milnes, 1994). Faults with incohesive fault rocks have been described by several authors and are generally interpreted as the result of
Mesozoic or younger fault reactivation (Fossen et al., 1997; Andersen et al., 1999; Larsen et al., 2003) but have so far not been dated in the study area.

\section{Dating shallow crustal faults}

Fault gouge is the material typically targeted for the dating of shallow crustal faults. It is an incohesive, finegrained ( $<30 \%$ visible fragments) fault rock, which may or may not be foliated (Sibson, 1977; Chester et al., 1985; Snoke \& Tullis, 1998). It is composed of finely crushed host-rock material as well as authigenic minerals (mostly phyllosilicates) that grew syn- or postkinematically in the fault (Vrolijk \& van der Pluijm, 1999; Solum et al., 2005). Illite is one of these newly grown minerals, and since illite fixes potassium in its crystal structure and can retain the radiogenic daughter product argon over many millions of years, it is amenable to radiometric dating by the $\mathrm{K}-\mathrm{Ar}$ or $\mathrm{Ar}-\mathrm{Ar}$ method (e.g., review by Clauer, 2013). Depending on the mineralogy of the host rock and availability and chemistry of fluids, illite can grow by illitisation of smectite or dissolution and reprecipitation of pre-existing clays (in clay-bearing host rocks; e.g., Vrolijk \& van der Pluijm, 1999; Solum et al., 2005; Haines \& van der Pluijm, 2008), by retrograde hydration reactions of feldspar and mica (mainly in crystalline host rocks; e.g., Zwingmann \& Mancktelow, 2004; Siebel et al., 2010; Zwingmann et al., 2010b) or even by direct neocrystallisation from a fluid phase. The growth of illite during fault activity is promoted by a number of factors, including temperature (frictional heating and advective heating by hydrothermal fluids), grain comminution (increased surface area), strain (increase of crystal defects) and changes in fluid composition (mainly availability of potassium) and fluid/rock ratio (Vrolijk \& van der Pluijm, 1999; Yan et al., 2001).

\section{Illite and temperature}

Beyond its usefulness as a geochronometer, illite can also provide temperature information. This is best studied in pelitic rocks, where a continuous transformation from smectite to mixed-layer illite/smectite (I/S) to discrete illite and finally to muscovite records the reaction progress through diagenesis and low-grade metamorphism (e.g., Hunziker et al., 1986; Merriman \& Peacor, 1999). Three different parameters are temperature-sensitive:

(1) The illite crystallinity can be described by the Kübler index (KI; Kübler, 1964), which is defined as the full width at half the maximum height (FWHM, measured in $\Delta^{\circ} 2 \theta$ ) of the normalised $10 \AA$ illite peak. The illite crystallinity is a measure of crystallite thickness, but is also influenced by structural distortion, e.g., 
interlayering with expandable smectite (Eberl \& Velde, 1989). The KI is inversely correlated to the diagenetic-metamorphic grade, i.e., metamorphic muscovite has lower KI values than diagenetic illite. Based on the KI, Kübler (1967) defined three zones: the diagenetic zone $(\mathrm{KI}>0.42)$, the anchizone $(0.42>$ $\mathrm{KI}>0.25)$ and the epizone $(0.25>\mathrm{KI})$. The diagenetic zone can further be divided into the early $(\mathrm{KI}>1.0)$ and the late diagenetic zone $(1.0>\mathrm{KI}>0.42)$. The anchizone is commonly divided into the low $(0.42>$ $\mathrm{KI}>0.3)$ and the high anchizone $(0.3>\mathrm{KI}>0.25)$. The lower and upper boundaries of the anchizone are typically assigned temperatures of $200^{\circ} \mathrm{C}$ and $300^{\circ} \mathrm{C}$, respectively; the boundary between early and late diagenesis corresponds to temperatures of approximately $100^{\circ} \mathrm{C}$ (e.g., Merriman \& Frey, 1999).

(2) Illite frequently occurs interlayered with smectite as I/S mixed-layer clays. The illite content in I/S is systematically increasing with burial depth, a process that is thought to be controlled mainly by temperature, but also reaction time and availability of potassium (Środoń \& Eberl, 1984). Borehole studies (e.g., Hower et al., 1976; Środoń \& Eberl, 1984; Jennings \& Thompson, 1986) show a consistent increase in illite (decrease in expandability) throughout early diagenesis. The illitisation of smectite starts at temperatures of $40-70^{\circ} \mathrm{C}$, the illite content in $\mathrm{I} / \mathrm{S}$ has increased to $60-80 \%$ at around $100^{\circ} \mathrm{C}$, and the illitisation of I/S is thought to be complete at around the anchizone-epizone boundary.

(3) Illite occurs as different polytypes, with mainly three polytypes found in nature: $1 \mathrm{M}_{\mathrm{d}}, 1 \mathrm{M}$ and $2 \mathrm{M}_{1}$ (e.g., Środoń \& Eberl, 1984; Grathoff \& Moore, 1996). Whether the two low-temperature $1 M_{d}$ and $1 \mathrm{M}$ polytypes are really distinct polytypes or endmembers of a single polytype is still controversial (e.g., Haines \& van der Pluijm, 2008) and they are here summarised as a single $1 \mathrm{M} / 1 \mathrm{M}_{\mathrm{d}}$ polytype. $1 \mathrm{M} / 1 \mathrm{M}_{\mathrm{d}}$ is the only polytype that can grow in the diagenetic zone, and at increasing temperatures it is irreversibly converted into $2 \mathrm{M}_{1}$ illite, which is the only polytype stable in the epizone (e.g., Merriman \& Peacor, 1999). In the anchizone, both polytypes can occur together.

\section{Interpretation of inclined age spectra}

In pelitic rocks, $\mathrm{K}-\mathrm{Ar}$ fine-fraction ages are usually dependent on the grain size of the analysed fraction, sometimes referred to as inclined age spectra (Pevear, 1999). This is generally attributed to mixing of predeposition detrital illite or muscovite, which dominates the coarser fractions, with post-deposition diagenetic illite, predominant in the finer fractions (e.g., Bailey et al., 1962; Hower et al., 1963; Pevear, 1992; Grathoff et al., $1998,2001)$. Faults commonly exhibit similar grain size- dependent age spectra (e.g., Pluijm et al., 2001; Solum et al., 2005; Löbens et al., 2011; Bense et al., 2014; Torgersen et al., 2015) that have been explained by two main processes:

(1) Grain-size dependent Ar loss:

$\mathrm{K}-\mathrm{Ar}$ dating relies on closed-system behaviour, i.e., no loss or gain of potassium or argon, thus it is critical to determine the effects of temperature and grainsize dependent Ar loss for reliable age interpretation. The closure temperature of coarse-grained $(100 \mu \mathrm{m})$ muscovite at cooling rates of $10^{\circ} \mathrm{C} / \mathrm{Ma}$ is around $405^{\circ} \mathrm{C}$ at a pressure of $5 \mathrm{kbar}$ (or $425^{\circ} \mathrm{C}$ at $10 \mathrm{kbar}$; Harrison et al., 2009). Based on the same diffusion parameters, Duvall et al. (2011) estimated the closure temperature of fine-grained muscovite $(2-0.05 \mu \mathrm{m})$ to be $250-$ $350^{\circ} \mathrm{C}$. This is consistent with empirical studies based on present-day borehole temperatures and estimated palaeotemperatures, which consistently indicate closure temperatures $>250^{\circ} \mathrm{C}$ for illite $<2 \mu \mathrm{m}$ (Hunziker et al., 1986; Wemmer \& Ahrendt, 1997). Importantly, these closure temperatures of $>250^{\circ} \mathrm{C}$ suggest that illite in shallow crustal faults generally crystallises below the closure temperature of the K-Ar system, providing crystallisation rather than cooling ages. In addition, during subsequent thermal episodes, quite significant reheating would be required to reset even the finest grain-size fractions. The short heating times of transient fault-related hydrothermal activity or frictional heating (as compared with the long-lasting temperature changes of regional metamorphism) make it even less likely that illite ages are reset unless temperatures significantly exceed the illite closure temperature (e.g., Zwingmann et al., 2010a; Torgersen et al., 2014). Thus, age dispersion in faults has only in rare cases been explained by grain size-dependent thermal resetting (e.g., Uysal et al., 2006; Zwingmann et al., 2010a).

(2) Mixing of different age components:

Authigenic illite cannot mechanically be separated from other fine-grained minerals. Therefore, the $\mathrm{K}-\mathrm{Ar}$ ages are bulk ages for the dated fine fractions, meaning that any K-bearing mineral present in the fine fractions will contribute to the age. Two main sources of 'contamination' must be considered: (1) Finely crushed host-rock minerals: They can be inherited from both sedimentary and crystalline host rocks (e.g., Vrolijk \& van der Pluijm, 1999; Pluijm et al., 2001; Zwingmann et al., 2010b; Torgersen et al., 2014). The finest fractions are generally less affected by, or even free from this type of contamination. (2) Inherited illite from earlier fault activity: Faults can become reactivated, producing several generations of fault-related illite (e.g., Löbens et al., 2011; Rahl et al., 2011; Davids et al., 2013; Viola et al., 2013; Bense et al., 2014; Torgersen et al., 2014). This is particularly relevant for faults in cooling basement terranes like West Norway, which can be repeatedly reactivated at lower and lower temperatures. Thus, high-temperature illite phases from earlier fault activity have the 
potential to survive low-temperature reactivations.

The three main K-bearing mineral phases encountered in fault gouges are illite/muscovite, K-feldspar and hornblende. Older, inherited illite/ muscovite is often cited as the cause of age dispersion in faults, but can be difficult to distinguish from faultgrown illite; it might be identified by its different polytype composition or high illite crystallinity. In certain environments, fine-grained host-rock muscovite might also be isotopically reset at the time of faulting, resulting in fine-fraction ages that are independent of the content of inherited muscovite (Vrolijk \& van der Pluijm, 1999; Zwingmann et al., 2010b). Besides illite/muscovite, K-feldspar is relatively common in fault gouges, especially in crystalline host rocks. The potential effect of $\mathrm{K}$-feldspar on fault gouge ages is complex. Several studies cite older, host rock-inherited K-feldspar as the cause of age dispersion (e.g., Zwingmann \& Mancktelow, 2004; Sasseville et al., 2008, 2012; Zwingmann et al., 2010a; Davids et al., 2013). Other studies suggest isotopic resetting at the time of faulting (Zwingmann et al., 2010b; Viola et al., 2013) or K-feldspar neocrystallisation during fault activity and associated hydrothermal fluid circulation (Choo \& Chang, 2000; Sasseville et al., 2008; Surace et al., 2011; Brockamp \& Clauer, 2013; Torgersen et al., 2015). Importantly, since fine-grained K-feldspar can have significantly lower closure temperatures $\left(350-150^{\circ} \mathrm{C}\right.$, dependent on the diffusion domain size; Lovera et al., 1989) than illite/muscovite, it could potentially even lower the age of fine fractions in fault gouges (Löbens et al., 2011; Bense et al., 2014), though no clear cases of this have been documented so far. The third mineral that has been observed to influence fault ages is hornblende (Torgersen et al., 2015). With a closure temperature of approximately $500^{\circ} \mathrm{C}$ (McDougall \& Harrison, 1999), isotopic resetting of hornblende in lower crustal faults is extremely unlikely and has so far never been observed. K-feldspar and hornblende are easily detectable and can be quantified with standard XRD analyses; their potential effect on the fault gouge ages can be assessed by contamination modelling (Zwingmann et al., 2010b; Viola et al., 2013; Torgersen et al., 2015).

\section{Analytical details}

Gouge-bearing faults are rarely exposed in the wet climate of West Norway, since the material is easily eroded to form valleys and fjords. The selection of sampling locations was therefore determined by the availability of suitable outcrops. In total, eleven samples were collected from nine different faults (Figs. 2, 3, 4; Table 1), and three grain-size fractions were dated per sample (except for sample BG-048 which yielded no fine fraction). Five faults are exposed in road cuts or quarries and four were encountered during the construction of tunnels. To minimise the effect of weathering in surface samples, any loose material and the outermost several centimetres to decimetres of the outcrop were removed before clay-rich material was collected from the core of the faults. Field descriptions and additional photographs can be found in Electronic Supplement 1.

The sample preparation and analyses were carried out at the Geoscience Centre, University of Göttingen (Germany), following the procedures described in Wemmer (1991) and Löbens et al. (2011). Analytical details can be found in Electronic Supplement 2. Samples were separated into the grain-size fractions $2-6 \mu \mathrm{m}$ (coarse) and $<2 \mu \mathrm{m}$ (medium) by differential settling in water. A fraction $<0.2 \mu \mathrm{m}$ (fine) was obtained by high-speed centrifugation. Both air-dried and ethylene glycol-solvated aliquots of each grain-size fraction were investigated by $\mathrm{X}$-ray diffraction (XRD) analysis, in order to determine their mineralogy, illite crystallinity and polytype composition. Potassium contents were measured in duplicate by flame photometry and the argon isotopic compositions were analysed with a Thermo Scientific Argus VI mass spectrometer coupled to a Pyrex glass extraction and purification vacuum line. $\mathrm{K}-\mathrm{Ar}$ ages were calculated using the decay constant of Steiger \& Jäger (1977).

\section{Results and interpretation}

Three grain-size fractions were analysed from all but one sample (BG-048) which yielded no fraction $<0.2 \mu \mathrm{m}$. Potassium contents range from 0.93 to 8.02 wt. $\% \mathrm{~K}_{2} \mathrm{O}$ and radiogenic ${ }^{40} \mathrm{Ar}$ from 53.02 and $98.73 \%$, indicating reliable analytical conditions for all samples (Table 2). Seven grain-size fractions (from samples BG-045a, BG-045b, BG-048 and BT) were analysed in duplicate and show excellent reproducibility (Table 2). The KAr ages range from 359 to $116 \mathrm{Ma}$ (Table 2; Fig. 5) and generally decrease with decreasing grain size. The spread of ages within one sample can be considerable, ranging from 11 to 194 myr. However, with the exception of one fault (BT), most faults yielded either predominantly Mesozoic ages or mostly Palaeozoic ages and have been grouped accordingly (Fig. 5). Based on their mineralogy, polytype composition and illite crystallinity, the age spectrum of each fault has been evaluated individually in order to determine the time(s) of fault activity.

\section{Mesozoic faults}

Four faults yielded predominantly Mesozoic ages, defining two periods of fault activity in the Late TriassicEarly Jurassic and in the Early Cretaceous: 

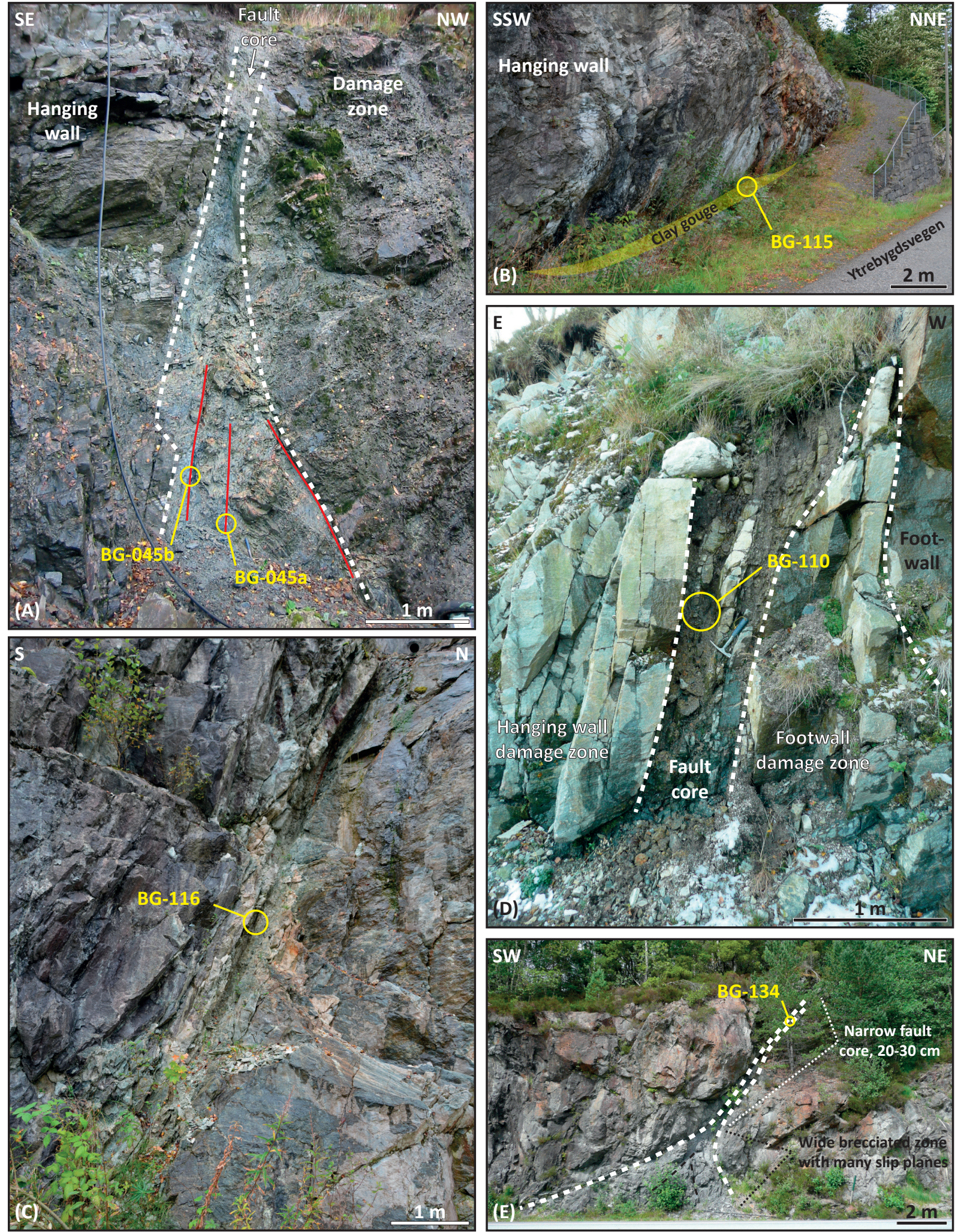

Figure 3. Field photographs of faults sampled in road-cuts or quarries. Additional photographs can be found in Electronic Supplement 1. (A) Døsjeneset (BG-045): red lines mark clay gouge layers in the lower part of the outcrop; (B) Ytrebygdsvegen (BG-115): clay gouge is exposed at the foot of the ourcrop; $(C)$ Terminalvegen (BG-116); (D) Olsvik Bäthavn (BG-110) and (E) Bjørsvik (BG-134): clay gouge is exposed in the upper part of the outcrop.

Døsjeneset, Sotra (BG-045a and BG-045b)

Two samples were collected from two distinct clay gouge bands within a 1-2 m-wide fault core: sample BG-045a from the centre of the fault and sample BG-045b closer towards the hanging wall (Fig. 3A). Both samples yielded gently inclined age spectra; the range of ages in each 


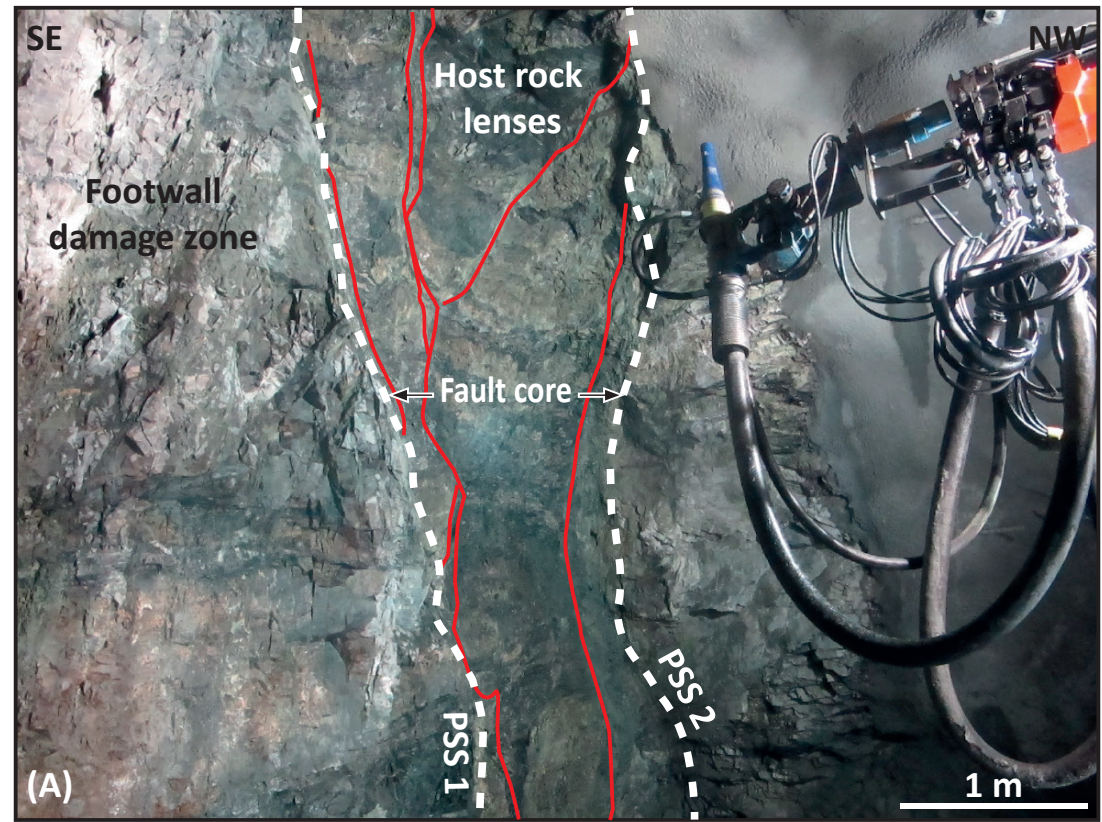

Figure 4. Field photograph of the fault sampled in Knappetunnelen $(K N)$, view of the western tunnel wall. Additional photographs can be found in Electronic Supplement 1. The fault core is bound by two principal slip surfaces (PSS1, PSS2). Sample KN1 was collected from PSS1, on the tunnel floor, approximately 3 m east of the western tunnel wall, and sample KN2 was collected from PSS2 along the eastern tunnel wall.

Table 1. Fault locations, orientations and descriptions (more detailed field descriptions in Electronic Supplement 1).

\begin{tabular}{|c|c|c|c|c|c|}
\hline Sample & Location & $\begin{array}{l}\text { UTM zone } 32 \\
\text { East, North }\end{array}$ & Strike /dip ${ }^{(1)}$ & Host rock & Description \\
\hline $\begin{array}{l}\text { BG-045a, } \\
\text { BG-045b }\end{array}$ & Døsjeneset & $\begin{array}{l}285450 \\
6695860\end{array}$ & $\begin{array}{c}022 / 80 \\
(\mathrm{ESE})\end{array}$ & $\begin{array}{l}\text { Banded and migmatitic } \\
\text { granitic gneiss of the } \\
\text { Øygarden Complex }\end{array}$ & $\begin{array}{l}\text { Small quarry opposite marina at Døsjeneset, Sotra; } 7 \mathrm{~m} \text { wide fault, } 0.3-2 \mathrm{~m} \text { wide } \\
\text { fault core with breccia and fault gouge; dark grey clay gouge in thin layers and } \\
\text { lenses within the brecciated fault core; footwall is strongly fractured. }\end{array}$ \\
\hline $\begin{array}{l}\mathrm{KN} 1, \\
\mathrm{KN}^{(3)}\end{array}$ & $\begin{array}{l}\text { Knappe- } \\
\text { tunnelen }\end{array}$ & $\begin{array}{l}293700 \\
6697080^{(2)}\end{array}$ & $\begin{array}{l}200 / 80 \\
(\text { WNW) }\end{array}$ & $\begin{array}{l}\text { Granitic and amphibo- } \\
\text { litic gneisses of the } \\
\text { Øygarden Complex }\end{array}$ & $\begin{array}{l}\text { Fault in Knappetunnelen, approx. } 1100 \mathrm{~m} \text { from northern (Liavatnet) end; } 20 \mathrm{~m} \\
\text { wide fault zone, } 1-2 \mathrm{~m} \text { wide fault core with lenses of greenish clay gouge; two } \\
\text { distinct slip surfaces: KN1 is close to the footwall with striations } 20 \rrbracket 214, \mathrm{KN} 2 \text { is } \\
\text { close to the hanging wall. }\end{array}$ \\
\hline BG-115 & $\begin{array}{l}\text { Ytrebygds- } \\
\text { vegen }\end{array}$ & $\begin{array}{l}293780 \\
6691400\end{array}$ & $\begin{array}{c}138 / 54 \\
(\mathrm{SW})\end{array}$ & $\begin{array}{l}\text { Meta-anorthosites of } \\
\text { the Lindås Nappe }\end{array}$ & $\begin{array}{l}\text { Road cut at road junction Storrinden/Ytrebygdsvegen, approx. } 300 \mathrm{~m} \text { north of } \\
\text { Kokstadvegen/Ytrebygdsvegen roundabout; } 10-20 \mathrm{~cm} \text { of greenish-grey clay } \\
\text { gouge exposed at foot of outcrop; striations on fault plane plunge } 20^{\circ} \text { towards } \\
\text { the SSE. }\end{array}$ \\
\hline BG-116 & $\begin{array}{l}\text { Terminal- } \\
\text { vegen }\end{array}$ & $\begin{array}{l}305380 \\
6701115\end{array}$ & $\begin{array}{c}068 / 61 \\
(\mathrm{SSE})\end{array}$ & $\begin{array}{l}\text { Metagabbros and } \\
\text { meta-anorthosites of } \\
\text { the Lindås Nappe }\end{array}$ & $\begin{array}{l}\text { Road cut along Terminalvegen, just west of road junction with } \\
\text { Hardangervegen, between Indre Arna and Espeland; } 1 \mathrm{~m} \text { wide damage zone, } \\
10-25 \mathrm{~cm} \text { wide brecciated fault core with light grey sandy clay gouge. }\end{array}$ \\
\hline BG-110 & $\begin{array}{l}\text { Olsvik } \\
\text { Båthavn }\end{array}$ & $\begin{array}{l}278930 \\
6705210\end{array}$ & $\begin{array}{l}335 / 79 \\
(\mathrm{ENE})\end{array}$ & $\begin{array}{l}\text { Granitic gneiss of the } \\
\text { Øygarden Complex }\end{array}$ & $\begin{array}{l}\text { Parking area of Olsvik Båtshavn (marina), west of Vindenes, Sotra; western } \\
\text { boundary of } 35 \mathrm{~m} \text { wide fracture zone; } 50 \mathrm{~cm} \text { wide brecciated fault core with } \\
\text { thin ( } \mathrm{mm} \text { to } \mathrm{cm} \text { ), dark grey to brown clay gouge layers. }\end{array}$ \\
\hline BG-048 ${ }^{(4)}$ & $\begin{array}{l}\text { Espelands- } \\
\text { tunnelen }\end{array}$ & $\begin{array}{c}296220 \\
6724020^{(2)}\end{array}$ & $\begin{array}{l}315 / 65^{(2)} \\
(\mathrm{NE})\end{array}$ & $\begin{array}{l}\text { Gneisses and } \\
\text { amphibolites of the } \\
\text { Lindås Nappe }\end{array}$ & $\begin{array}{l}\text { Fault in Espelandstunnelen (county road no. 57), close to Herland, Lindås; } 0.1 \\
\mathrm{~m} \text { wide clay zone parallel to the foliation. }\end{array}$ \\
\hline BG-134 & Bjørsvik & $\begin{array}{l}308065 \\
6727600\end{array}$ & $\begin{array}{l}158 / 54 \\
(\text { WSW) }\end{array}$ & $\begin{array}{l}\text { Granitic gneiss of } \\
\text { the Western Gneiss } \\
\text { Region, garnet- } \\
\text { micaschist }\end{array}$ & $\begin{array}{l}\text { Road cut along road no. E39 north of Bjørsvik; } 0.2 \mathrm{~m} \text { wide fault core of dark } \\
\text { grey to brown breccia and grey fault gouge in upper part of outcrop; fault splays } \\
\text { into a } 3 \mathrm{~m} \text { wide strongly brecciated zone in lower part of outcrop. }\end{array}$ \\
\hline $\mathrm{GT}^{(5)}$ & $\begin{array}{l}\text { Grønneviks- } \\
\text { tunnelen }\end{array}$ & $\begin{array}{l}298230 \\
6698380^{(2)}\end{array}$ & $\begin{array}{c}144 / 72 \\
(\mathrm{SW})\end{array}$ & $\begin{array}{l}\text { Granitic augengneiss } \\
\text { of the Øygarden } \\
\text { Complex }\end{array}$ & $\begin{array}{l}1043 \mathrm{~m} \text { from Møllendal-end of Grønnevikstunnelen; } 0.5 \mathrm{~m} \text { wide clay zone } \\
\text { within a fracture. }\end{array}$ \\
\hline $\mathrm{BT}^{(6)}$ & $\begin{array}{l}\text { Bjorøy- } \\
\text { tunnelen }\end{array}$ & $\begin{array}{l}289380 \\
6694980^{(2)}\end{array}$ & $310 / 90^{(2)}$ & $\begin{array}{l}\text { Conglomerate of the } \\
\text { Bjorøy Formation, } \\
\text { granitic gneiss of the } \\
\text { Øygarden Complex }\end{array}$ & $\begin{array}{l}\text { Fault zone in Bjorøytunnelen, approx. } 900 \mathrm{~m} \text { from southern (Bjorøy) entrance; } \\
5-10 \mathrm{~m} \text { wide fault zone with breccia and gouge; somewhat consolidated, } \\
\text { brownish-grey fault gouge in } \mathrm{cm} \text { - to } \mathrm{dm} \text {-thick continuous bands. }\end{array}$ \\
\hline
\end{tabular}

${ }^{(1)}$ Strike is determined using the right-hand rule, direction of dip in parentheses, ${ }^{(2)}$ Approximate positions and orientations (from map). Samples provided by ${ }^{(3)} \mathrm{E}$. Bastesen (UiB) and T. Kirkjeby (Statens Vegvesen), ${ }^{(4)}$ H. Hauso (Statens Vegvesen), ${ }^{(5)}$ J. B. A. Rasmussen (UiB, see Rasmussen (2013) for more information) and ${ }^{(6)} \mathrm{H}$. Fossen $($ UiB, see Fossen et al. (1997) for more information). 
sample is less than $15 \mathrm{Ma}$ and the total range of ages in both samples is less than $30 \mathrm{Ma}$ (Fig. 5). Together, all ages could be taken as evidence of fault activity around the Triassic-Jurassic boundary. However, the mineralogy, polytype composition and illite crystallinity of the samples reveal more details.

Sample BG-045b gave Late Triassic to earliest Jurassic ages of $216 \pm 6,213 \pm 5$ and $200 \pm 4 \mathrm{Ma}$ for the coarse, medium and fine fractions, respectively. The sample is composed mainly of chlorite and discrete illite/muscovite, with minor I/S (20\% illite) and traces of quartz (Table 2). Illite/muscovite is predominantly of the $1 \mathrm{M} / 1 \mathrm{M}_{\mathrm{d}}$ polytype. The $2 \mathrm{M}_{1}$ polytype amounts to $11 \%$ in the coarse fraction and approximately $9 \%$ and $5 \%$ in the medium and fine fractions, respectively (details in Electronic Supplement 3). Sample BG-045a gave slightly younger, latest TriassicEarly Jurassic ages of $202 \pm 4,195 \pm 4$ and $187 \pm 5 \mathrm{Ma}$ for the coarse, medium and fine fractions, respectively (Table 2 ). The sample contains mainly chlorite, with minor I/S (20\% illite) and discrete illite/muscovite and traces of quartz and K-feldspar. XRD polytype identification shows the illite in the medium and fine fractions to be exclusively of the $1 \mathrm{M} / 1 \mathrm{M}_{\mathrm{d}}$ polytype (details in Electronic Supplements 2,3). The coarse fraction, on the other hand, probably contains small amounts $(<10 \%)$ of $2 \mathrm{M}_{1}$ illite/ muscovite, but an exact quantification is difficult due to the low content of illite/muscovite in the sample and strongly overlapping chlorite and K-feldspar peaks.

The KI values range from 0.42 to $0.52 \Delta^{\circ} 2 \theta$ in BG-045b and from 0.44 to $0.51 \Delta^{\circ} 2 \theta$ in BG-045a, which corresponds to temperatures just below the diagenetic zone-anchizone boundary $\left(150-200^{\circ} \mathrm{C}\right)$. The predominance of the $1 \mathrm{M} / 1 \mathrm{M}_{\mathrm{d}}$ polytype in both samples is consistent with these temperatures. However, the minor amount of $2 \mathrm{M}_{1}$ illite/muscovite could not have grown under diagenetic conditions. It must have grown at higher temperatures and could be inherited from an earlier episode of faulting or from the host rock. The medium and fine fractions of sample BG-045a are free of $2 \mathrm{M}_{1}$ illite/muscovite. They overlap in age, within their uncertainties, and give a mean age of $191 \mathrm{Ma}$, which we interpret as the best age estimate for the neocrystallisation of $1 \mathrm{M} / 1 \mathrm{M}_{\mathrm{d}}$ illite in the fault. The slightly older ages of the coarse fraction of sample BG-045a and all fractions of sample BG-045b are attributed to minor contamination with the older $2 M_{1}$ illite/muscovite. The exact age of this older component is difficult to constrain, due to the small quantities of $2 \mathrm{M}_{1}$ illite/muscovite, but it could be much older than the $1 \mathrm{M} / 1 \mathrm{M}_{\mathrm{d}}$ illite, possibly as old as the muscovite cooling ages of the host rock. While no muscovite ages are available from the Øygarden Complex, $\mathrm{Ar}-\mathrm{Ar}$ cooling ages from hornblende (408-404 Ma; higher closure temperature than muscovite) and biotite (401 $\mathrm{Ma}$; lower closure temperature than muscovite) limit the expected host-rock muscovite cooling ages to $404-401 \mathrm{Ma}$ (Boundy et al., 1996; Fossen \& Dunlap, 1998).

\section{Knappetunnelen (KN1 and $\mathrm{KN} 2$ )}

Samples KN1 and KN2 were collected from two distinct, clay gouge-bearing slip planes along a 1-2 m-wide fault encountered during drilling of Knappetunnelen (Fig. 4). Sample KN2 is characterised by a gently inclined age

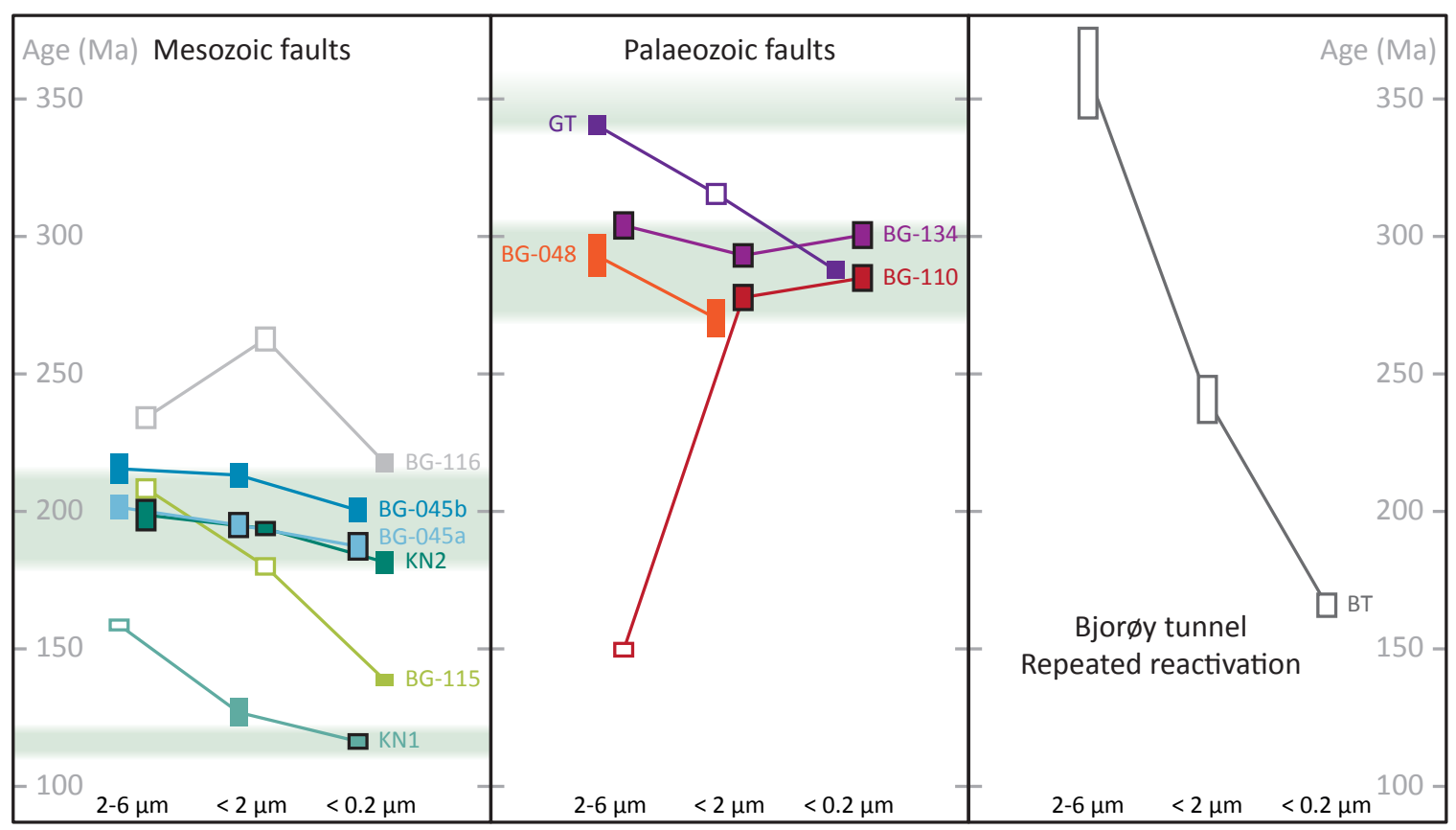

Figure 5. Age spectra of dated faults (age plotted against grain-size fraction). Box heights correspond to the analytical uncertainties ( $\pm 2 \sigma$ ). Filled symbols with black frame represent ages that are interpreted to correspond directly to fault activity; filled symbols without frame are ages close to the age of fault activity (affected by only minor contamination); empty symbols represent ages that are interpreted as mixed or otherwise unexplained ages. Green bars represent periods of fault activity (see also Fig. 6). 


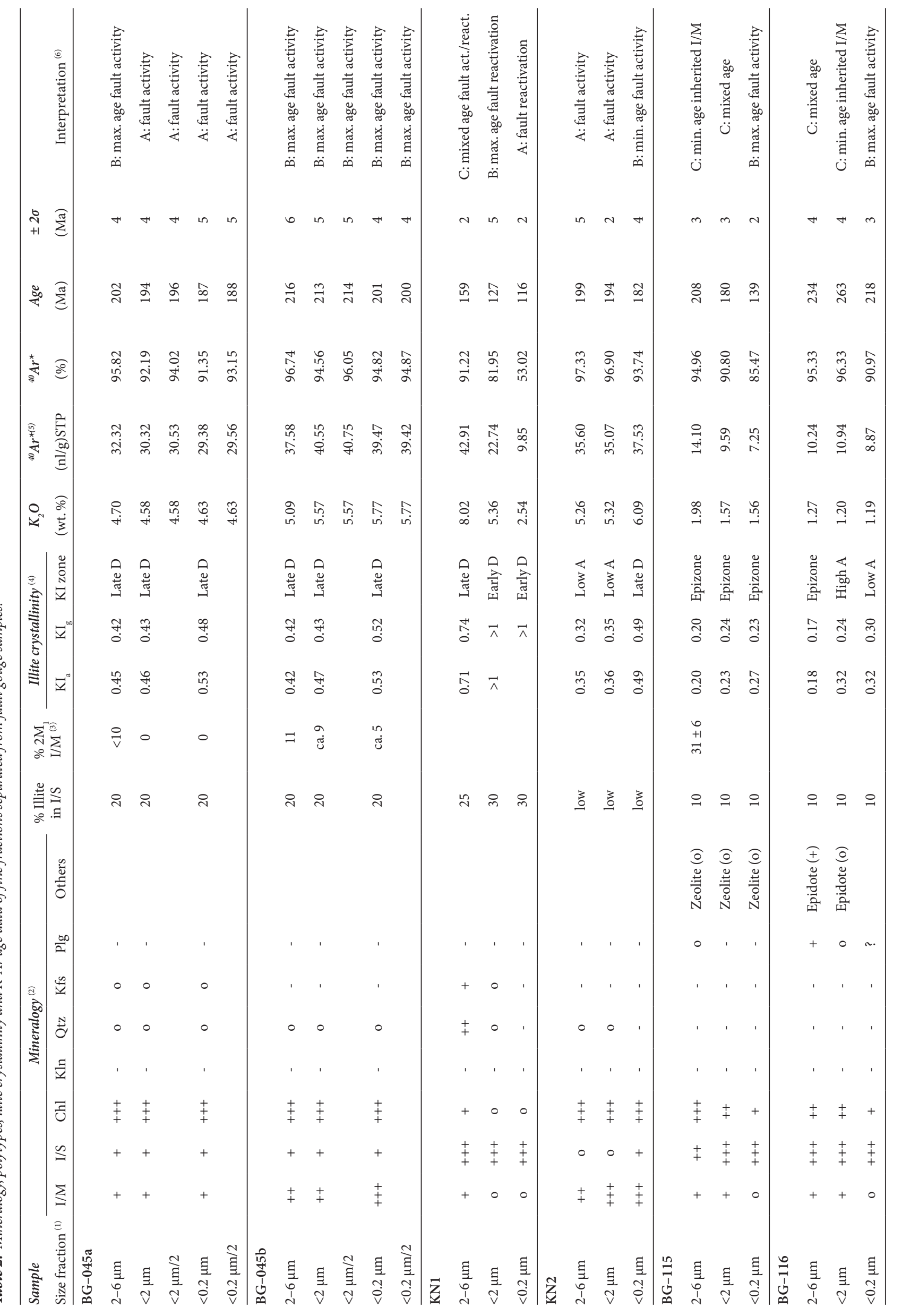




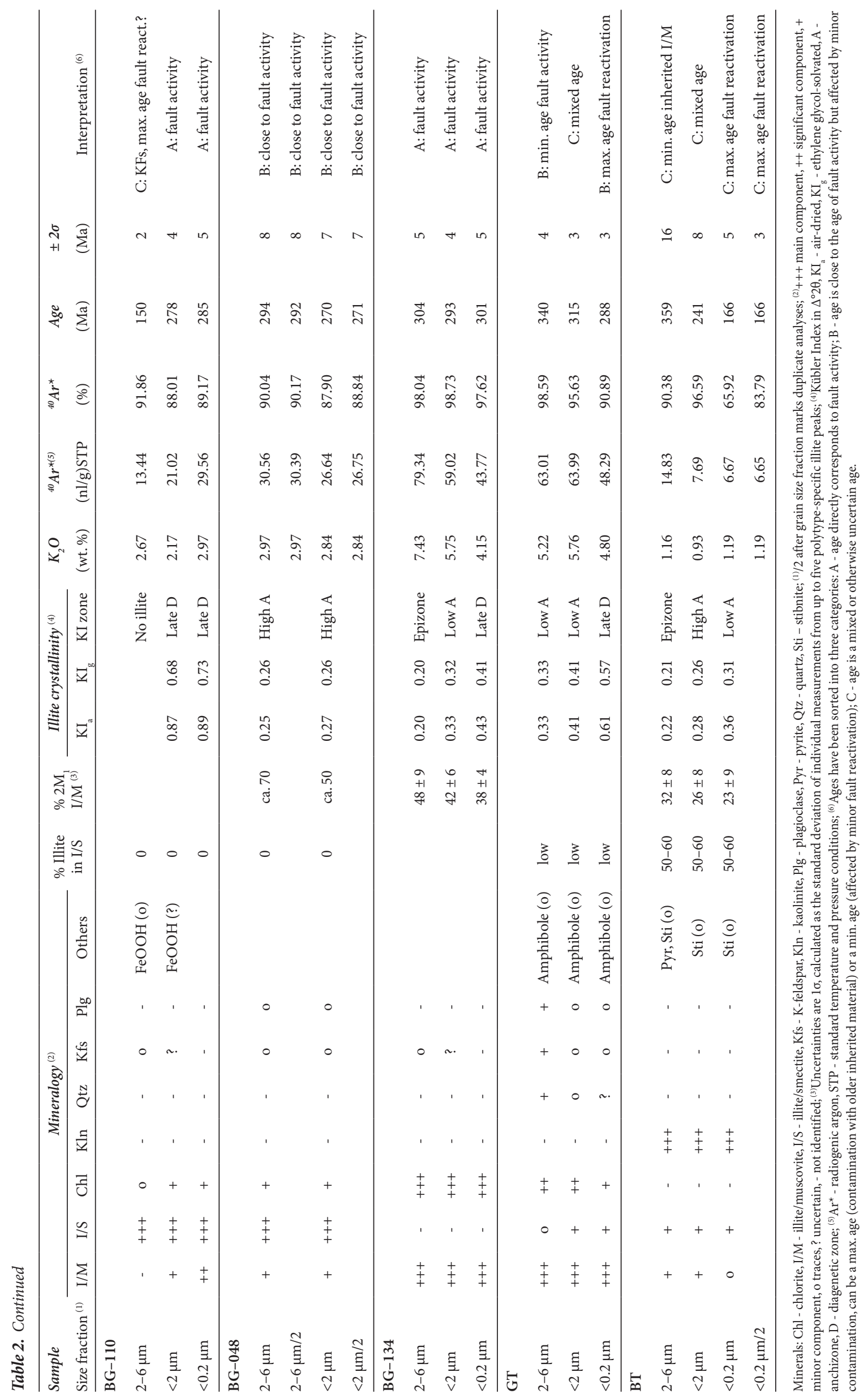


spectrum with Early Jurassic ages (Fig 5). The coarse and medium fractions overlap in age (199 \pm 5 and 194 $\pm 5 \mathrm{Ma})$ and are mineralogically very similar: They are both composed mainly of discrete illite/muscovite and chlorite, with only traces of I/S and quartz (Table 2). Their KI values of $0.34-0.35 \Delta^{\circ} 2 \theta$ indicate temperatures corresponding to the low anchizone $\left(200-250^{\circ} \mathrm{C}\right)$. The fine fraction yielded a slightly younger age of $182 \pm 4$ $\mathrm{Ma}$. I/S is present in larger amounts than in the coarser fractions, though discrete illite/muscovite and chlorite are still the main components. The KI value is noticeably higher $\left(0.49 \Delta^{\circ} 2 \theta\right)$, which would correspond to lower temperatures (late diagenetic zone, $<200^{\circ} \mathrm{C}$ ). I/S peaks are not well developed, but the illite component in I/S is most likely low $(<20 \%)$, which suggests formation at even lower temperatures $\left(<100^{\circ} \mathrm{C}\right)$.

Sample KN1 gave significantly younger, Late Jurassic to Early Cretaceous ages of $159 \pm 2,127 \pm 5$ and $116 \pm 3 \mathrm{Ma}$ for the coarse, medium and fine fractions, respectively (Fig. 5; Table 2). The sample is also mineralogically different, being dominated by I/S (25-30\% illite). The coarse fraction additionally contains quartz and minor discrete illite/muscovite, chlorite and K-feldspar. The medium fraction contains traces of these minerals, while the fine fraction only contains traces of discrete illite/ muscovite and chlorite. The KI values of the medium and fine fractions are $>1 \Delta^{\circ} 2 \theta$ and suggest therefore temperatures corresponding to the early diagenetic zone $\left(<100^{\circ} \mathrm{C}\right)$, which is consistent with the predominance of smectite-rich $\mathrm{I} / \mathrm{S}$. The KI value of the coarse fraction is lower $\left(0.72 \Delta^{\circ} 2 \theta\right)$, which would correspond to higher temperatures (deep diagenetic zone, $100-200^{\circ} \mathrm{C}$ ).

Taking both samples together, these data document two periods of fault activity (Fig. 6): The coarse and medium fractions of KN2 contain almost exclusively discrete illite/ muscovite as the K-bearing phase; only traces of I/S are present. Their ages overlap within errors and we interpret these ages to date a first period of illite neocrystallisation in the fault in the earliest Jurassic, at temperatures above $200^{\circ} \mathrm{C}$ and producing relatively coarse-grained discrete illite. The medium and fine fractions of $\mathrm{KN} 1$, on the other hand, are strongly dominated by I/S and contain only traces of discrete illite. They also gave similar ages that should be close to the age of pure I/S. The fine fraction is the least contaminated by discrete illite and is also free of additional K-feldspar. Its Early Cretaceous age $(116 \mathrm{Ma})$ is therefore interpreted as the best age estimate for a period of fault reactivation at much lower temperatures $\left(<100^{\circ} \mathrm{C}\right)$, producing mostly fine-grained $\mathrm{I} / \mathrm{S}$. The coarse fraction of $\mathrm{KN} 1$ and fine fraction of KN2 both contain a mixture of first-generation discrete illite and second-generation I/S; their ages are consequently interpreted as mixed ages. Fault reactivation seems to have localised along the slip plane represented by $\mathrm{KN} 1$ and even the fine fraction of KN2 is still mostly dominated by discrete illite and therefore close to the age of the first period of fault activity.
Ytrebygdsvegen (BG-115) and Terminalvegen (BG116)

The faults sampled along Ytrebygdsvegen (BG-115; Fig. 3B) and Terminalvegen (BG-116; Fig. 3C) are both hosted in meta-anorthositic rocks of the Lindås Nappe. The samples are mineralogically similar (Table 2): Both are dominated by smectite-rich I/S (10\% illite), which indicates growth at low-temperature conditions $\left(<100^{\circ} \mathrm{C}\right)$. Both samples also contain well crystallised discrete illite/muscovite that must have grown at an earlier time at much higher temperatures or could be inherited from the host rock. The amount of discrete illite/muscovite is decreasing with grain size to only trace amounts in the fine fractions. Both samples additionally contain chlorite, the amount decreasing with grain size, as well as minor amounts/traces of plagioclase. Sample BG-115 additionally contains traces of zeolite in all fractions and sample BG-116 has minor/trace epidote in the coarse and medium fractions. KI values of the discrete illite/muscovite in the coarse fraction are very low in both samples $\left(0.17-0.20 \Delta^{\circ} 2 \theta\right)$, suggesting temperatures corresponding to the epizone $\left(>300^{\circ} \mathrm{C}\right)$. The medium and fine fractions have somewhat higher KI values of $0.23-0.25 \Delta^{\circ} 2 \theta$ for BG-115 and $0.28-0.31 \Delta^{\circ} 2 \theta$ for BG-116, yet still corresponding to epizone-high anchizone temperatures. These KI values are strongly dominated by the sharp peaks of the well crystallised discrete illite/muscovite and are not representative of the low-temperature I/S component in the samples. The polytype composition of the coarse fraction of sample BG-115 is approximately $30 \% 2 \mathrm{M}_{1}$ and $70 \% 1 \mathrm{M} / 1 \mathrm{M}_{\mathrm{d}}$, but was difficult to determine due to low illite contents and interference with other peaks (details in Electronic Supplement 3). Most likely, the $2 \mathrm{M}_{1}$ polytype represents the high-temperature discrete illite/muscovite, while the $1 \mathrm{M} / 1 \mathrm{M}_{\mathrm{d}}$ polytype is present as illite in $\mathrm{I} / \mathrm{S}$. Due to very low illite contents in the medium and fine fractions, polytype analyses were not attempted. In sample BG-116, the determination of polytypes was prevented by the low illite/muscovite contents, as well as the presence of both plagioclase and epidote, which cause significant peak interference.

Altogether, there is clear evidence of mixing between an older high-temperature illite/muscovite and a younger low-temperature I/S component in both samples, which is reflected by their wider age ranges of $70 \mathrm{Ma}$ (BG-115) and $45 \mathrm{Ma}$ (BG-116; Fig. 5). In both samples, the fine fraction is the least contaminated, with only trace amounts of the high-temperature, discrete illite/ muscovite, and is thought to approximate the growth of the low-temperature, smectite-rich I/S during fault activity. The fine fraction of sample BG-115 yielded an Early Cretaceous age of $139 \pm 2 \mathrm{Ma}$. The age has to be considered as a maximum age for I/S growth, though, since a small amount of discrete illite/muscovite is still present, and, with a much higher K-concentration than the illite-poor I/S, even this minor contamination can have an effect on the age (Fig. 6). The fault might 


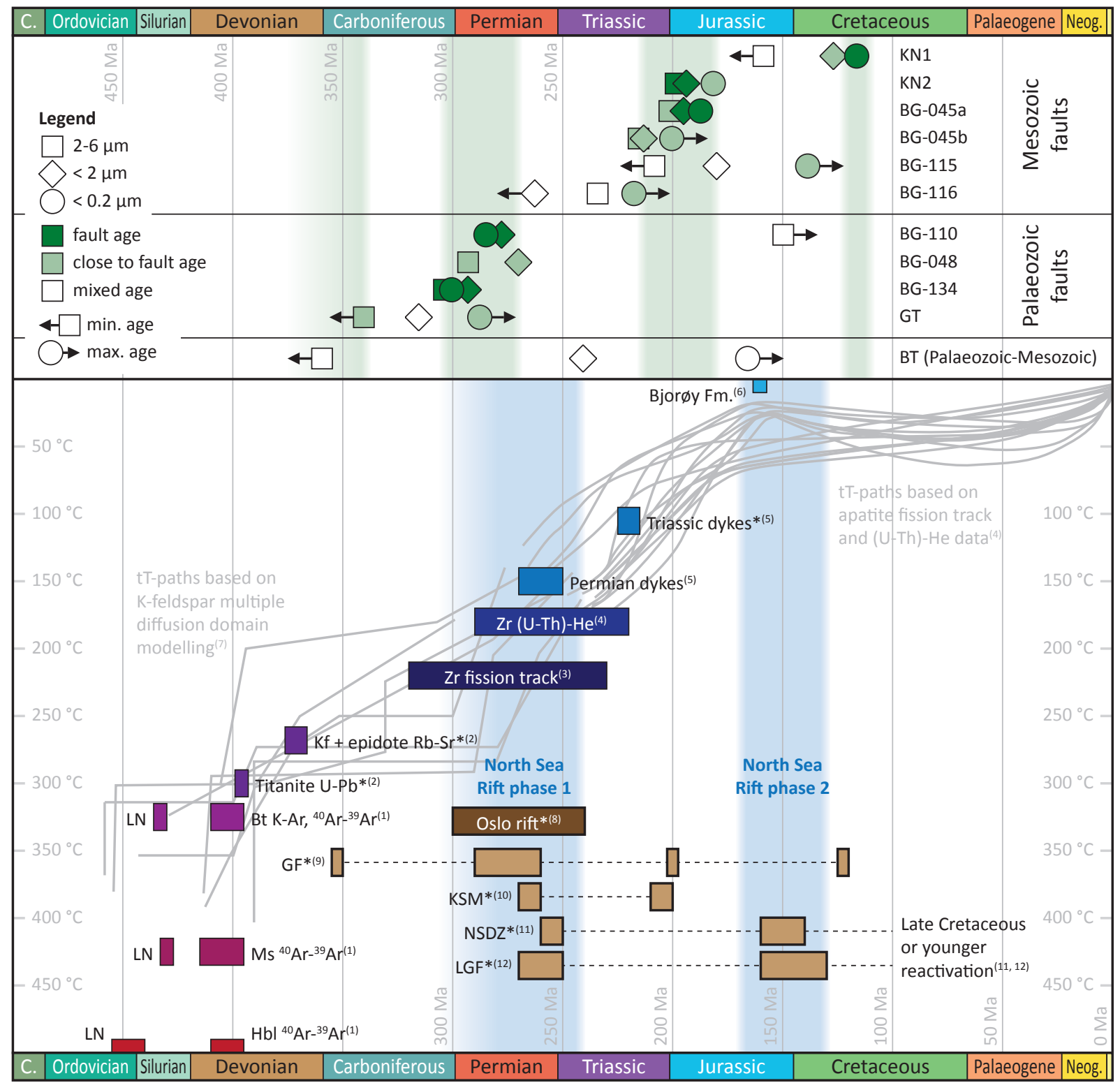

Figure 6. Comparison of fault gouge K-Ar fine-fraction ages and periods of fault activity (green bars) identified in this study with published geochronological data from western Norway. Upper part of figure: The fault gouge K-Ar fine-fraction ages are colour coded according to their geological significance: dark green - ages correlated directly to fault activity, light green - ages that are affected by some minor contamination from older or younger material but that are interpreted to be still relatively close to the age of fault activity, white - mixed or otherwise unexplained ages with little to no geological significance. Lower part of figure: Accumulated thermochronological and tectonic data from West Norway. ${ }^{*}$ marks geochronological data with limited or no temperature information. Abbreviations: Bt - biotite, GF - Goddo Fault, Hbl hornblende, Kf - K-feldspar, KSM - Kongsberg silver mines, LGF - Lordal-Gjende Fault Zone, LN - Lindås Nappe, Ms - muscovite, NSDZ Nordfjord-Sogn Detachment Zone, tT - time-Temperature, Zr - zircon. References: (1) Boundy et al. (1996), Fossen \& Dallmeyer (1998), Fossen \& Dunlap (1998); (2) Larsen et al. (2003); (3) Andriessen \& Bos (1986), Leighton (2007), R. Kumar, pers. comm. (2010); (4) Ksienzyk et al. (2014); (5) Forseth et al. (1976), Løvlie \& Mitchell (1982), Fossen \& Dunlap (1999), Torsvik et al. (1997); (6) Fossen et al. (1997); (7) Dunlap \& Fossen (1998), Fossen \& Dunlap (1998); (8) Sundvoll \& Larsen (1990, 1993), Sundvoll et al. (1990), Pedersen et al. (1995), Dahlgren et al. (1996, 1998), Corfu \& Dahlgren (2008); (9) Viola et al. (2016); (10) Torgersen et al. (2015), (11) Torsvik et al. (1992), Eide et al. (1997); (12) Andersen et al. (1999).

have been active at the same time as the fault in Knappetunnelen (KN1), in the Early Cretaceous. The coarse and medium fractions gave Late Triassic and Early Jurassic ages of $208 \pm 3$ and $180 \pm 3 \mathrm{Ma}$, respectively. The age of the medium fraction is interpreted as a mixed age without geological significance. The coarse fraction contains the largest amount of the high-temperature discrete $2 \mathrm{M}_{1}$ illite/muscovite component (approx. $30 \%$ ). However, due to the additional presence of significant amounts of $1 \mathrm{M} / 1 \mathrm{M}_{d}$ illite in I/S also in this size fraction, the Late Triassic age has to be considered a minimum age for the crystallisation of $2 \mathrm{M}_{1}$ illite/muscovite. The illite/ muscovite might indeed be much older, either grown during an earlier period of fault activity or inherited 
from the host rock. The high crystallinity (low KI) of the discrete illite/muscovite seems to favour the latter and relatively coarse muscovite flakes can be observed on foliation planes in the meta-anorthositic host rock (Electronic Supplement 1). Muscovites from the Lindås Nappe have been dated to be Silurian (c. $430 \mathrm{Ma}$; Boundy et al., 1996; Fossen \& Dunlap, 1998).

Without any polytype information, the interpretation of the age spectrum of sample BG-116 is even more speculative. The fine grain-size fraction of $B G-116$ yielded a Late Triassic age of $218 \pm 3 \mathrm{Ma}$. With only trace amounts of the older discrete illite/muscovite present, this age should be close to the age of I/S growth in the fault, but again has to be interpreted as a maximum age. Fault activity might have been contemporaneous with the Late Triassic-Early Jurassic faults at Døsjeneset (BG-045a, b) and in Knappetunnelen (KN2). The Permo-Triassic ages $(263 \pm 4$ and $234 \pm 4 \mathrm{Ma})$ of the medium and coarse size fractions are most likely mixed ages without much geological significance. Considering the very high crystallinity (low KI) of the illite/muscovite in the coarse fraction and the overall similarities with BG-115, the discrete illite/muscovite might well have been inherited from the Lindås Nappe host rocks.

\section{Palaeozoic faults}

Four faults gave mostly Palaeozoic ages, defining fault activity in the latest Carboniferous-Permian and the onset of fault-related illite crystallisation in the Early Carboniferous.

\section{Olsvik Båthavn (BG-1 10)}

For sample BG-110 (Fig. 3D) the age trend is reversed, as the coarse fraction gave the youngest, Late Jurassic, age of $150 \pm 2 \mathrm{Ma}$ (Fig. 5). The Permian ages for the medium and fine fractions overlap within their uncertainties at $278 \pm 4$ and $285 \pm 5 \mathrm{Ma}$, respectively. Mineralogically, the sample is strongly dominated by smectite (Table 2 ). Discrete illite is present in the medium and fine fractions, but was not found in the coarse fraction. All size fractions further contain minor/trace amounts of chlorite, and the coarse fraction includes traces of $\mathrm{K}$-feldspar and Fe-oxide-hydroxides. The sample yielded KI values of 0.77 to $0.81 \Delta^{\circ} 2 \theta$, indicative of temperatures corresponding to the late diagenetic zone $\left(100-200^{\circ} \mathrm{C}\right)$. The overlapping Early Permian ages of the medium and fine fractions are interpreted as the age of illite crystallisation in the fault (Fig. 6). Smectite should be mostly converted to illite at temperatures above $100^{\circ} \mathrm{C}$, thus the large amount of smectite in the sample might indicate a later reactivation at temperatures too low for illite to grow and therefore undatable. The Late Jurassic age of the coarse fraction is somewhat enigmatic. Though it contains no illite, its K-concentration is similar to that of the finer fractions, suggesting that most of the potassium might come from the K-feldspar, and the age is essentially a K-feldspar age. Fine-grained K-feldspar has a potentially lower closure temperature $\left(350-150^{\circ} \mathrm{C}\right.$; Lovera et al., 1989) than illite/muscovite $\left(425-250^{\circ} \mathrm{C}\right.$; Harrison et al., 2009; Duvall et al., 2011) and could therefore be reset at lower temperatures, yielding younger ages. However, this requires fault activity at temperatures exceeding the closure temperature of K-feldspar; the temperatures indicated by the high $\mathrm{KI}$ values of the sample $\left(100-200^{\circ} \mathrm{C}\right)$ are barely high enough and hostrock temperatures in the Late Jurassic were well below the closure temperature of K-feldspar (Rohrman et al., 1995; Ksienzyk et al., 2014). Alternatively, synkinematic authigenesis of K-feldspar has been documented in faults in southern Norway (Torgersen et al., 2015) and might also have occurred here. In either case, the age of the coarse fraction might be interpreted as the maximum age for a Late Jurassic or younger reactivation of the fault, which produced authigenic K-feldspar and abundant smectite.

\section{Espelandstunnelen (BG-048)}

A sample from a fault in Espelandstunnelen did not yield a grain-size fraction $<0.2 \mu \mathrm{m}$. The medium and coarse fractions gave Early-Mid Permian ages of $270 \pm 7$ and $293 \pm 8$ Ma, respectively (Fig. 5; Table 2). Mineralogically, the sample is strongly dominated by smectite, with moderate to minor discrete illite/muscovite, minor chlorite and traces of K-feldspar and plagioclase. The KI values $\left(0.26 \Delta^{\circ} 2 \theta\right)$ correspond to the high anchizone $\left(250-300^{\circ} \mathrm{C}\right)$. The polytype composition was analysed and both $2 \mathrm{M}_{1}$ and $1 \mathrm{M} / 1 \mathrm{M}_{\mathrm{d}}$ polytypes are present but interference with smectite and feldspar peaks makes their exact quantification impossible. $2 \mathrm{M}_{1}$ is clearly the dominant polytype (approximately 70\%) in the coarse fraction, while the medium fraction contains roughly equal amounts of the $1 \mathrm{M} / 1 \mathrm{M}_{\mathrm{d}}$ and $2 \mathrm{M}_{1}$ polytypes (details in Electronic Supplement 3). The coexistence of $2 \mathrm{M}_{1}$ and $1 \mathrm{M} / 1 \mathrm{M}_{\mathrm{d}}$ polytypes is possible in the anchizone; thus, both polytypes could have grown during a single episode of Permian fault activity. Alternatively, both could be mixed ages, between an older (Carboniferous?) generation of $2 \mathrm{M} 1$ illite/muscovite and a younger (Triassic?) generation of $1 \mathrm{M} / 1 \mathrm{Md}$ illite. The difference in age for the two size fractions is not much greater than their combined uncertainties, and the lack of a fine fraction could be used as an argument against Early Mesozoic fault reactivation. Based on this, we cautiously interpreted the Early-Mid Permian ages of this sample as illite growth during (or at least close to) fault activity at this time (Fig. 6). The abundance of smectite in the sample suggests a later reactivation of the fault at low temperatures, which did not produce illite and can therefore not be dated by the K-Ar method.

\section{Bjørsvik (BG-134)}

The fault in Bjørsvik (Fig. 3E) seems to exploit a relatively weak layer of garnet-mica schist in otherwise finegrained granitic (mylonitic) gneisses. The abundance of mica in the immediate host rock increases the risk 
of contamination of the fault gouge with inherited muscovite. Mineralogically, all three size fractions are composed of discrete illite/muscovite and chlorite. Additionally, traces of $\mathrm{K}$-feldspar are present in the coarse and medium fractions. Both polytypes are present, with 48,42 and $38 \% 2 \mathrm{M}_{1}$ in the coarse, medium and fine fractions, respectively (details in Electronic Supplement 3 ). Remarkably, the sample yielded an essentially flat age spectrum with ages of $304 \pm 5,293 \pm 4$ and $301 \pm 5 \mathrm{Ma}$ for the coarse, medium and fine fractions, respectively (Fig. 5; Table 2). The ages are overlapping within their uncertainties and are independent of $\% 2 \mathrm{M}_{\text {; }}$, we interpret them as a single period of fault activity in latest Carboniferous-earliest Permian times (Fig. 6). Thus, muscovite that might have been incorporated from the host rock is either completely recrystallised or has been isotopically reset. The KI value of the coarse fraction is $0.2 \Delta^{\circ} 2 \theta$, suggesting temperatures higher than $300^{\circ} \mathrm{C}$. This is in agreement with crystallisation of $2 \mathrm{M}_{1}$ illite/ muscovite but higher than host-rock temperatures indicated by independent thermochronological studies (Fig. 5; Dunlap \& Fossen, 1998). Additional heat might have been provided by frictional heating or circulation of hydrothermal fluids during fault activity. The higher KI values of the medium and fine fraction $(0.32$ and 0.42 $\Delta^{\circ} 2 \theta$, respectively) track rapid cooling back to host-rock temperatures following this temperature spike. They correspond to the low anchizone where the $1 \mathrm{M} / 1 \mathrm{M}_{\mathrm{d}}$ polytype is stable. While both $2 \mathrm{M}_{1}$ illite/muscovite and $1 \mathrm{M} / 1 \mathrm{M}_{\mathrm{d}}$ illite grew during the same faulting episode and have almost the same age, the $2 \mathrm{M}_{1}$ illite/muscovite most likely grew at high temperatures during the initial thermal spike, while the $1 \mathrm{M} / 1 \mathrm{M}_{\mathrm{d}}$ illite grew slightly later when the system had cooled again sufficiently.

\section{Grønnevikstunnelen (GT)}

A $0.5 \mathrm{~m}$-wide clay zone was sampled in Grønnevikstunnelen (Rasmussen, 2013). The main component of the sample is discrete illite/muscovite (Table 2). However, various other minerals are present in minor to trace amounts, namely chlorite, smectite-rich I/S, quartz, $\mathrm{K}$-feldspar, plagioclase and hornblende. The amount of I/S is increasing with decreasing grain size, while the amount of chlorite and the non-clay phases is generally decreasing. KI values of $0.33-0.59 \Delta^{\circ} 2 \theta$ place the sample in the low-anchizone to late-diagenetic zone and at temperatures of $100-250^{\circ} \mathrm{C}$. The sample yielded Early Carboniferous to Early Permian ages of $340 \pm 4 \mathrm{Ma}, 316$ $\pm 3 \mathrm{Ma}$ and $288 \pm 3 \mathrm{Ma}$ for the coarse, medium and fine fractions, respectively (Fig. 5). These relatively old ages raise the question as to whether the illite/muscovite in the sample is fault-related or at least partly inherited from the wall rock. The illite crystallinity is much lower (KI values are much higher) than would be expected for inherited host-rock muscovite, even for the coarsest fraction. Consequently, we interpret the age of the coarse fraction in this sample as a minimum age for the earliest fault-related illite crystallisation in the area in Early Carboniferous times (Fig. 6). A comparison with other samples strengthens this interpretation: all samples for which considerable host rock contamination is suspected (BG-115, BG-116, BT) are characterised by much higher illite crystallinities (low KI values), as would be expected for muscovite from crystalline rocks. The Early Permian age of the fine fraction is interpreted as a maximum age for fault reactivation, most likely contemporaneous with faults on Sotra (BG-110) and in the Lindas area (BG048).

\section{Bjorøytunnelen (BT): Palaeozoic-Mesozoic ages}

A sample from Bjorøytunnelen shows by far the largest spread in ages of almost 200 myr (Fig. 5; Table 2). The coarse fraction yielded a latest Devonian-earliest Carboniferous age of $359 \pm 16 \mathrm{Ma}$. The medium fraction is Mid Triassic in age at $241 \pm 8 \mathrm{Ma}$, and the fine fraction gave a Mid Jurassic age of $166 \pm 5 \mathrm{Ma}$. The main component of all three size fractions is kaolinite, with minor discrete illite/muscovite, mixed-layer I/S and traces of sulphide minerals. I/S peaks are poorly developed, so the $50-60 \%$ illite in I/S should be taken as a rough estimate. Both polytypes are present with 32,26 and $23 \% 2 \mathrm{M}_{1}$ in the coarse, medium and fine fractions, respectively, although the large amount of kaolinite makes polytype quantification difficult and also these values should be taken as estimates (details in Electronic Supplement 3). The KI values range from $0.22 \Delta^{\circ} 2 \theta$ for the coarse fraction to 0.27 and $0.34 \Delta^{\circ} 2 \theta$ for the medium and fine fractions, respectively, suggesting generally high temperatures from $>300^{\circ} \mathrm{C}$ to $200^{\circ} \mathrm{C}$ (epizoneanchizone). However, the presence of I/S indicates illite growth at much lower temperatures $\left(<100^{\circ} \mathrm{C}\right)$. The steeply inclined age spectrum and coexistence of hightemperature (epizone), discrete, 2M1 illite/muscovite with low-temperature (diagenetic) I/S suggest mixing of at least two generations of illite/muscovite. However, the relatively narrow range of $\% 2 \mathrm{M} 1$ cannot account for the wide range of ages unless the old end member is much older than the 408-401 Ma hornblende and biotite cooling ages for the Øygarden Complex host rocks (Boundy et al., 1996; Fossen \& Dunlap, 1998). A simple two end-member mixing model can therefore not be applied to this sample and we consider it very likely that more than two generations of illite/muscovite are present. Based on the low KI value of the coarse fraction, the oldest illite/muscovite in the sample might well be inherited from the host rock. Both discrete $2 \mathrm{M}_{1}$ and $1 \mathrm{M} / 1 \mathrm{M}_{d}$ illite might have grown during Late Palaeozoic-Early Mesozoic fault activity. The youngest fault reactivation caused growth of low-temperature I/S, but due to mixing with $\sim 23 \% 2 \mathrm{M}_{1}$ illite/muscovite, the fine fraction can only give a maximum age for this event (Fig. 6). Thus, the illite data indicate fault reactivation in the Late Jurassic or younger, which is consistent with Oxfordian (157.3-163.5 Ma) sedimentary rocks that were caught up in the fault zone (Fossen et al., 1997). 


\section{Discussion}

Four periods of fault activity have been identified from the dataset presented here (Fig. 6): (1) the onset of faultrelated illite crystallisation in Late Devonian-Early Carboniferous times ( $>340 \mathrm{Ma}),(2)$ widespread fault activity in the latest Carboniferous-Mid Permian (305$270 \mathrm{Ma}),(3)$ a significant period of Late Triassic-Early Jurassic faulting (215-180 Ma) and finally (4) Early Cretaceous fault reactivation (120-110 Ma). Placing these in the context of the post-Caledonian history of western Norway shows a generally good agreement with interpretations derived from other methods and a clear interaction between offshore and onshore processes.

\section{Devonian-Early Carboniferous: extensional collapse of Caledonian crust}

Post-Caledonian exhumation to upper crustal depths is well documented in the study area by $\mathrm{K}-\mathrm{Ar}$ and $\mathrm{Ar}-\mathrm{Ar}$ hornblende, muscovite and biotite ages (Fig. 6). Locally, these thermochronometers record pre-Scandian (455$430 \mathrm{Ma})$ metamorphism and cooling, for example in the Lindås Nappe (Boundy et al., 1996; Fossen \& Dunlap, 1998); however, the majority of ages are late- to postCaledonian. Hornblende ages, indicating cooling through $500^{\circ} \mathrm{C}$ (e.g., McDougall \& Harrison, 1999), range from 410 to $395 \mathrm{Ma}$ (Boundy et al., 1996; Fossen \& Dunlap, 1998). Muscovite and biotite ages (cooling below $425^{\circ} \mathrm{C}$ (muscovite) and $350-300^{\circ} \mathrm{C}$ (biotite); McDougall \& Harrison, 1999; Harrison et al., 2009) fall between 415395 Ma (Fossen \& Dallmeyer, 1998; Fossen \& Dunlap, 1998). East of the study area, mica ages have been divided into an older group (415-405 Ma) representing Scandian thrusting and a larger, younger group (404-395 Ma) representing post-Caledonian extension and cooling (Fossen \& Dunlap, 1998, 2006). The transition from Caledonian contraction to post-Caledonian extension happened quickly within a few million years. The similarities in post-Caledonian cooling ages between hornblende and mica thermochronometers indicate extensional collapse and rapid cooling from temperatures around or above $500^{\circ} \mathrm{C}$ to below $300^{\circ} \mathrm{C}$ immediately following the Caledonian Orogeny. Modelling of Ar-Ar K-feldspar data (Dunlap \& Fossen, 1998) also suggests initial fast cooling to temperatures around $300^{\circ} \mathrm{C}$ in the early-middle Devonian, followed by a period of stability or slow cooling from Mid Devonian to Late Carboniferous times (380-300 Ma; Fig. 6).

While the initial stages of extension were accommodated by backsliding along the basal décollement zone and later development of large extensional shear zones (Mode I and II extension; Fossen, 2000), rapid cooling soon allowed for the formation of brittle deformation structures. The oldest brittle deformation is documented by a Mid Devonian (396 Ma) U-Pb age of titanite grown in fault- related fractures in the Øygarden Complex and Bergen Arc System (Larsen et al., 2003). These faults belong to the Set I fractures of Larsen et al. (2003) that formed under NW-SE extension and semiductile to semibrittle conditions. $\mathrm{Rb}-\mathrm{Sr}$ two-point isochron ages of epidote and alkali feldspar from hydrothermal alteration around Set I fractures range from 370 to $360 \mathrm{Ma}$, indicating that Set I faulting, or at least hydrothermal circulation along Set I faults, was still active in the Late Devonian (Larsen et al., 2003). The absence of Early-Mid Devonian illite ages suggests that temperatures at this time were still too high to allow the formation of fault gouge. The oldest illite age that we interpret as a minimum age for faultrelated illite crystallisation is Early Carboniferous (340 Ma; coarse fraction of sample GT). Early Carboniferous (355-350 Ma) illite ages have also been reported from the Goddo Fault, south of our study area (Viola et al., 2016). These illite data suggest that brittle deformation continued during the waning stages of orogenic collapse into the Late Devonian-Early Carboniferous.

\section{Late Carboniferous-Permian: magmatism and rifting}

The Late Carboniferous-Permian was a period of widespread rifting and locally intense magmatism in northern Europe (e.g., Neumann et al., 2004). In southern Norway, the Oslo Rift developed during this time (Neumann et al., 1992, 2004; Larsen et al., 2008). The oldest sedimentary rocks associated with the Oslo Rift, the Asker Group, were deposited during the initial rift stage in the upper Pennsylvanian (Eagar, 1994; Olaussen et al., 1994). Magmatic activity associated with rifting has been dated by the Rb-Sr method at 300-240 Ma (Fig. 5; Sundvoll \& Larsen, 1990, 1993; Sundvoll et al., 1990). However, more reliable $\mathrm{U}-\mathrm{Pb}$ data ranging from 300 to $277 \mathrm{Ma}$ (Pedersen et al., 1995; Dahlgren et al., 1996, 1998; Corfu \& Dahlgren, 2008) suggest that magmatism may have been shorter lived. Fault activity during the waning stages of magmatism (270-260 Ma) has been documented by $\mathrm{K}-\mathrm{Ar}$ fault gouge geochronology on the western flank of the Oslo Rift (Torgersen et al., 2015).

In the North Sea, Early Triassic rifting is well documented, but the onset of rifting is poorly constrained (Badley et al., 1988; Gabrielsen et al., 1990; Steel \& Ryseth, 1990; Roberts et al., 1995; Færseth, 1996; Odinsen et al., 2000). In the central North Sea, volcanism associated with rifting has been dated at 300-260 Ma (Stemmerik et al., 2000; Heeremans et al., 2004), i.e., contemporaneous with volcanism in the Oslo Rift. In the northern North Sea, synrift volcanic rocks have not yet been discovered. While many authors argue for a Permian age of rift initiation (e.g., Gabrielsen et al., 1990; Steel \& Ryseth, 1990; Færseth, 1996), both Early Triassic (Roberts et al., 1995; Lepercq \& Gaulier, 1996) and Permo-Carboniferous ages (Pascal \& Cloetingh, 2002; Heeremans \& Faleide, 2004) have been suggested. 
In onshore western Norway, evidence of increased tectonic activity in the Permian is widespread and includes:

(1) Increased cooling rates: Modelling of $\mathrm{Ar}-\mathrm{Ar}$ $\mathrm{K}$-feldspar data indicates accelerated cooling from 300 to $250 \mathrm{Ma}$ during which temperatures decreased on average by $80^{\circ} \mathrm{C}$ (Dunlap \& Fossen, 1998), corresponding to a removal of several kilometres of overburden $(2-4 \mathrm{~km}$, assuming a geothermal gradient between 20 and $\left.40^{\circ} \mathrm{C}\right)$. This period of increased cooling is also reflected in zircon fission track (320$230 \mathrm{Ma}$; Andriessen \& Bos, 1986; Leighton, 2007; R. Kumar, pers. comm., 2010) and zircon (U-Th)He data (310-215 Ma; Ksienzyk et al., 2014) which record cooling through approximately $220^{\circ} \mathrm{C}$ and $170^{\circ} \mathrm{C}$, respectively (Fig. 6).

(2) Magmatic activity: The coastal regions of western Norway were intruded by coast-parallel dykes during a regime of $\mathrm{E}(\mathrm{NE})-\mathrm{W}(\mathrm{SW})$ extension (Fossen, 1998; Valle et al., 2002). K-Ar, Ar-Ar and palaeomagnetic age determinations indicate two pulses of dyke intrusion (Færseth et al., 1976; Løvlie \& Mitchell, 1982; Torsvik et al., 1997; Fossen \& Dunlap, 1999). The older group is Permian (270-250 Ma; Fig. 6) in age, and a relationship with the formation of the Oslo Rift and the North Sea rift system has been suggested (Færseth et al., 1976, 1995; Fossen \& Dunlap, 1999; Valle et al., 2002).

(3) Fault activity: Field evidence shows that there was fault activity both before and after the intrusion of the Permian dykes (Færseth et al., 1976; Torsvik et al., 1997; Fossen, 1998; Valle et al., 2002). On Sotra, Set II faults of Larsen et al. (2003) tend to strike parallel to the dykes and, at one locality, one of the dykes underwent cataclastic deformation. Based on these relationships it has been suggested that Set II fractures, which reflect a similar extension direction as the dykes, are associated with dyke intrusion in the Permian (Fossen, 1998; Larsen et al., 2003). This is consistent with the Ar-Ar age spectrum of altered $\mathrm{K}$-feldspar from the alteration zone along a fault in the Øygarden Complex, which was interpreted to date fault-related hydrothermal alteration around 250 $\mathrm{Ma}$ (Fossen et al., 2016). The Permian age of sample BG-110, collected from one of the NNW-SSEstriking Set II faults on Sotra also corroborates this interpretation. Three other faults that yielded latest Carboniferous to Mid Permian ages (305-270 Ma; BG-048, BG-134 and GT) show similar orientations (strike between NNW-SSE and NW-SE; Fig. 7), in general agreement with the extension direction at this time. Also the Goddo Fault, a NNW-SSE-striking fault south of our study area, shows major illite authigenesis during E-W extension in the Permian (290-260 Ma; Viola et al., 2016). Additionally, Late Permian brittle reactivation of large Devonian shear zones, namely the Lærdal-Gjende Fault System and the Nordfjord-Sogn Detachment Zone, has been dated both palaeomagnetically and by Ar-Ar analyses of cataclasites (Torsvik et al., 1992; Eide et al., 1997; Andersen et al., 1999).

Collectively, previously published and new data confirm that large parts of onshore western Norway were affected by extensional tectonics during the latest Carboniferous and Permian, generally supporting an early onset of rifting in the northern North Sea, contemporaneous with rift-related volcanism in the central North Sea and the Oslo Rift.

Triassic-Early Jurassic:

differential uplift and erosion

Thermal modelling based on apatite fission track and apatite (U-Th)-He ages suggests that cooling rates remained relatively high $\left(2-3^{\circ} \mathrm{C} / \mathrm{Ma}\right)$ throughout the Triassic and Early Jurassic, followed by much slower cooling $\left(<1^{\circ} \mathrm{C} / \mathrm{Ma}\right)$ in the Late Jurassic and Cretaceous (Rohrman et al., 1995; Leighton, 2007; Ksienzyk et al., 2014). The Triassic-Early Jurassic cooling is generally interpreted as continued rift flank erosion following Permo-Triassic North Sea rifting. Recent thermochronological studies have shown that the
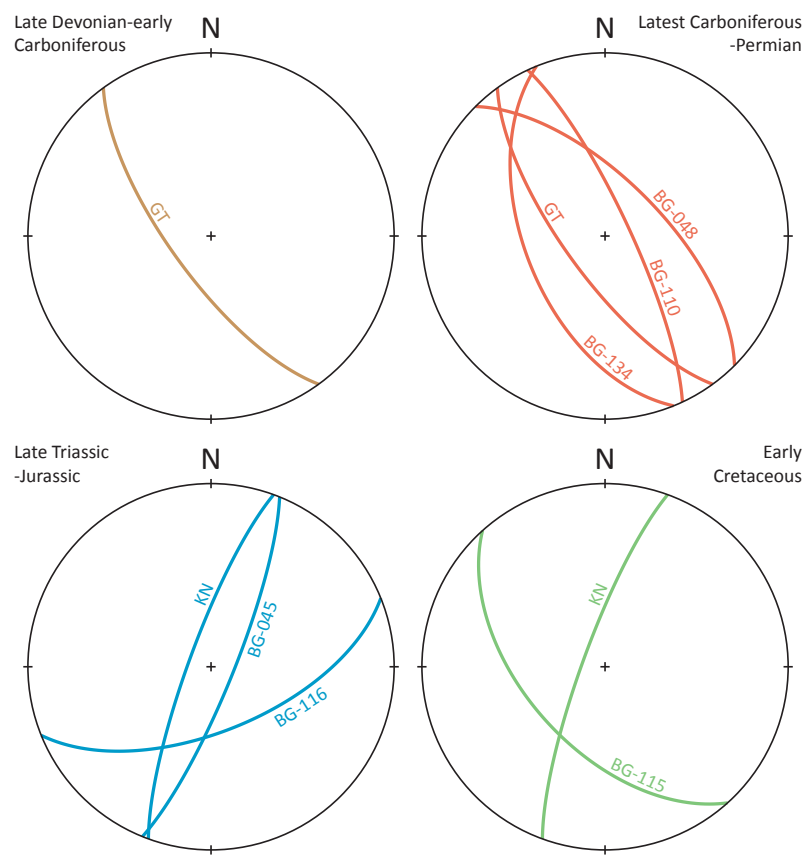

Equal area, lower hemisphere projection (Schmidt net)

Figure 7. Fault orientations for each of the four periods of fault activity identified in this study. Latest Carboniferous-Permian faults all strike NNW-SSE to NW-SE, in accordance with E(NE)-W(SW) extension at this time. Late Triassic-Early Jurassic faults strike NNESSW to ENE-WSW. 
distribution of apatite fission track and (U-Th)-He ages is tectonically controlled, i.e., that ages are offset across faults, and fault-bound blocks have cooling histories that are distinctly different from their neighbours (Leighton, 2007; Ksienzyk et al., 2014). Differential uplift of faultbound blocks and movement along the faults separating these blocks must therefore have occurred throughout at least the Early-Mid Mesozoic. Similar findings have previously been reported from the Møre-Trøndelag Fault Complex farther to the north (Redfield et al., 2004, 2005).

$\mathrm{K}-\mathrm{Ar}$ fine fraction ages from three faults in the Bergen area (BG-045, BG-116, KN2) now confirm an Early Mesozoic (215-170 Ma) period of fault activity (Fig. 6). The Late Triassic additionally saw a second pulse of dyke intrusion in the coastal areas of southwestern Norway, dated by $\mathrm{K}-\mathrm{Ar}$ and $\mathrm{Ar}-\mathrm{Ar}$ analyses at $230-210 \mathrm{Ma}$ (Færseth et al., 1976; Fossen \& Dunlap, 1999). The dykes are preferentially coast-parallel and their opening modes suggest that they intruded during continued E-W extension (Fossen, 1998; Valle et al., 2002). The Jurassic faults dated here strike between NNE-SSW and ENE-WSW (Fig. 7), which would be more consistent with NW-SE extension; this direction might represent a local trend, though. Farther south, the NNW-SSE-striking Goddo Fault preserves evidence of fault reactivation during E-W extension, associated with synkinematic illite growth in the earliest Jurassic (200 Ma; Viola et al., 2016). In southern Norway, $\mathrm{N}-\mathrm{S}$-striking faults show significant fault activity in the Late Triassic (210-200 Ma; Torgersen et al., 2015). Both of these studies highlight the significance of this event over wide areas of southern and western Norway. This Late Triassic-Early Jurassic episode of onshore fault activity falls in a time interval that has, in offshore areas, traditionally been regarded as a period of relative tectonic quiescence. Onshore faulting clearly postdates Permo-Triassic (Phase 1) rifting and predates Late Jurassic (Phase 2) rifting (Fig. 6). Accounts of inter-rift tectonic activity offshore have long been limited to 'mild Late Triassic stretching' accompanied by increased fault activity (Gabrielsen et al., 1990) and 'more active intrabasinal tectonics' during the deposition of a RhaetianSinemurian postrift megasequence (Steel \& Ryseth, 1990). Recent studies based on offshore seismic data, however, document significant Late Triassic-Early Jurassic inter-rift fault activity along several faults in the northern North Sea (Oseberg area and northern Utsira High; Refvem, 2016; Deng et al., in review).

\section{Mid Jurassic-Palaeogene: renewed rifting and eventual breakup}

A second rift phase in the northern North Sea during the Mid-Late Jurassic was strongly focused in the Viking Graben (e.g., Færseth, 1996), thus affecting onshore tectonics to a lesser degree. Thermal modelling based on apatite fission track and (U-Th)-He data indicates significantly slower cooling rates since the Mid Jurassic, or even minor sedimentary burial of the coastal regions
(Ksienzyk et al., 2014). At some time during the Late Jurassic to Early Cretaceous, the stress field for the North Sea region changed from E-W extension to NW-SE extension (Bell et al., 2014, and references therein) and active rifting shifted from the mostly $\mathrm{N}$-S-oriented Viking Graben to the NE-SW-oriented future North Atlantic, culminating in the Early Eocene in continental breakup (Doré et al., 1999).

While Late Jurassic fault activity is documented in onshore western Norway, it seems to be less pronounced than during Permian rifting. The discovery of tectonically disturbed Late Jurassic sedimentary rocks in a fault zone in Bjorøytunnelen near Bergen (the Bjorøy Formation; Fossen et al., 1997) indicates fault activity postdating the Oxfordian (163.5-157.3 Ma) deposition age. Jurassic sedimentary strata some $20 \mathrm{~km}$ west of the present coastline were also affected by faulting in the Late Jurassic (Fossen, 1998). The sample from the fault in Bjorøytunnelen (sample BT) shows signs of repeated fault reactivation and possibly inheritance from the host rocks. These complexities prevent us from obtaining a precise age for the fault. However, a late Mid Jurassic (166 $\mathrm{Ma}$ ) maximum age for the last period of fault-related illite crystallisation is consistent with Late Jurassic fault activity. Other than this somewhat uncertain age from the fault in Bjorøytunnelen, no illite ages directly correlate to the second North Sea rift phase (Fig. 6). However, Late Jurassic-Early Cretaceous fault reactivation has been reported from the Lærdal-Gjende Fault System and Nordfjord-Sogn Detachment Zone farther north (Torsvik et al., 1992; Eide et al., 1997; Andersen et al., 1999).

Two of the faults dated here (BG-115, KN1) define an even younger, Early Cretaceous period of onshore fault activity. Similar Early Cretaceous (125-120 Ma) illite ages were found in a NNE-SSW-striking fracture zone on Goddo Island, south of our study area (Viola et al., 2016) and are interpreted as a period of dilation, fluid infiltration and associated host-rock alteration. Bell et al. (2014) describe an eastward migration of fault reactivation during Phase 2 rifting, with the faults closest to the Viking Graben being reactivated first and those farther away from the rift axis later. It is thus possible that fault reactivation only reached onshore Norway during the Mid-Early Cretaceous. Alternatively, these younger faults could be related to Cretaceous rifting in the future North Atlantic. No isotopic signature of the Eocene opening of the North Atlantic has so far been recognised in the study area. However, the Lærdal-Gjende Fault farther to the northeast yielded ages as young as Early Palaeocene (Ksienzyk, 2012; Fossen et al., 2016).

One reason for the relative dearth of documented onshore fault activity contemporaneous with Late Jurassic (Phase 2) North Sea rifting and Eocene continental breakup is certainly the rift geometry. Rifting in the Late Jurassic was much more focused along the offshore Viking Graben than earlier Phase 1 rifting (e.g., Færseth, 1996; 
Odinsen et al., 2000); thus, onshore faults might have experienced only relatively minor reactivation. A second contributing factor might be the limitations of the dating method. By Late Jurassic times, basement rocks in western Norway had cooled to well below $100^{\circ} \mathrm{C}$ (Fig. 6; Rohrman et al., 1995; Leighton, 2007; Ksienzyk et al., 2014), making illite authigenesis in faults more difficult and possibly dependent on additional heating by friction of hydrothermal circulation during faulting. Some faults (KN1, BG-115) clearly still produced illite (in I/S) at least until the Early Cretaceous. Many other faults, on the other hand, contain abundant smectite or very smectiterich I/S in addition to the higher-temperature discrete illite phases. Smectite is present in tunnel samples as well as surface samples, making a weathering origin unlikely; this smectite most likely grew during fault reactivation. Several faults might thus have been active during either Phase 2 North Sea rifting or the North Atlantic opening without producing datable clay minerals.

\section{Temperatures during fault gouge formation}

Most depictions of fault zones at depth show fault gouge as a fault rock restricted to the uppermost crust (1-4 km; e.g., Sibson, 1977), corresponding to temperatures below $120^{\circ} \mathrm{C}$ (assuming an average geothermal gradient of $30^{\circ} \mathrm{C} / \mathrm{km}$ ). Yet many of the faults dated here were active in the Palaeozoic and Early Mesozoic, when the basement rocks that host them still remained at significantly higher temperatures (Figs. 6, 8). The earliest illite generation that we interpret as fault-related (coarse fraction in sample GT) gave an Early Carboniferous minimum age of 340 Ma. Similar Early Carboniferous illite ages (355-350 Ma) were also found in the Goddo Fault farther south (Viola et al., 2016). Thermal modelling based on Ar-Ar K-feldspar multiple diffusion domain analyses (Dunlap \& Fossen, 1998) suggests temperatures in the range of $250-300^{\circ} \mathrm{C}$ at this time, corresponding to depths of $8-10 \mathrm{~km}$ (Fig. 8). Illite crystallinity (KI) values corresponding to the anchizone $\left(200-300^{\circ} \mathrm{C}\right)$ are generally in agreement with these temperature estimates.

In latest Carboniferous-Mid Permian (305-270 Ma) time, Ar-Ar K-feldspar multiple diffusion domain modelling (Dunlap \& Fossen, 1998) indicates cooling of the basement from $250-300^{\circ} \mathrm{C}$ to about $150^{\circ} \mathrm{C}$ (corresponding to 8-10 and $5 \mathrm{~km}$ depth, respectively). Faults that were active during this time period (BG-048, BG-110, BG-134, reactivation of GT) mostly yielded KI values corresponding to the anchizone $\left(200-300^{\circ} \mathrm{C}\right)$ or late diagenetic zone $\left(100-200^{\circ} \mathrm{C}\right)$ and plot on the general cooling path of their host rocks (Fig. 8). An exception is the coarse fraction of sample BG-134 with $\mathrm{KI}$ values corresponding to the epizone $\left(>300^{\circ} \mathrm{C}\right)$. The excess temperatures required for the growth of the coarse and well crystallised illite in this sample might be explained by either frictional heating or circulation of hot fluids early during fault activity. The fault cooled quickly back to ambient host-rock temperatures as is evident from the higher KI values of the only slightly younger medium and fine fractions.

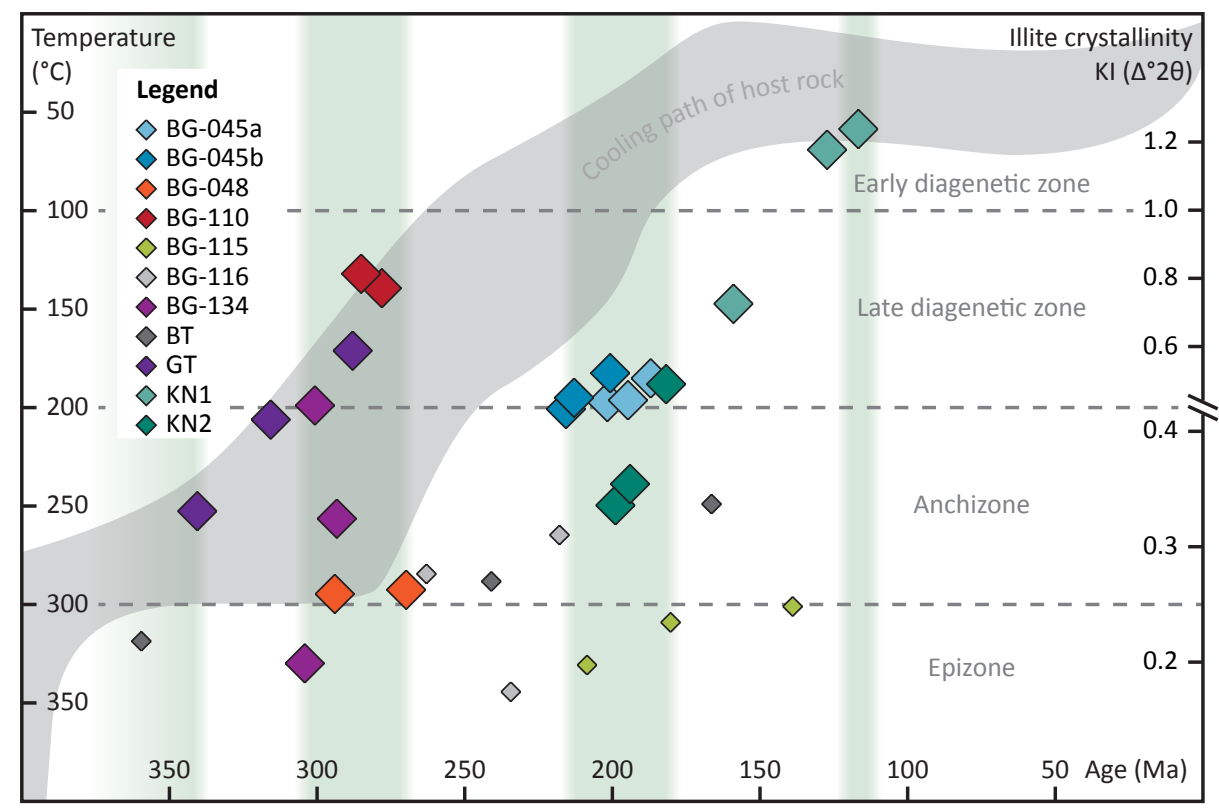

Figure 8. General cooling path of the study area (grey swath, time vs. temperature, based on the thermochronological data accumulated in Fig. 6) and illite crystallinity of the dated fault gouge fine fractions (coloured symbols, age vs. KI values). Green bars represent periods of fault activity. The illite crystallinity is not linearly correlated with temperature and the illite crystallinity scale has been adjusted so that KI values for illite crystallinity zone boundaries line up with the corresponding temperatures for these boundaries. Note the scale change at $0.42 \Delta^{\circ} 2 \theta$. KI values plotting on the host-rock cooling path suggest fault activity at ambient host-rock temperatures. KI values plotting below the host-rock cooling path indicate higher temperatures in the fault during illite growth than in the surrounding basement rocks. Some faults (smaller symbols) show contamination by host-rock muscovite and their (much too low) KI values are not representative of the illite grown in the fault. 
In the Late Triassic-Early Jurassic (215-180 Ma), thermal modelling based on apatite fission track and (U-Th)-He data (Ksienzyk et al., 2014) suggests hostrock temperatures between 50 and $150^{\circ} \mathrm{C}(1.7-5 \mathrm{~km})$. The KI values from the faults that were active during this time mostly plot around the anchizone-diagenetic zone boundary (around $200^{\circ} \mathrm{C}$ ) or even in the anchizone (medium and coarse fraction $\mathrm{KN} 2$ ), thus indicating somewhat higher temperatures (Fig. 8). The higher temperatures preserved in our fault gouge clays are likely due to frictional heating or convection of hydrothermal fluids in the faults.

Finally, in the Late Jurassic-Early Cretaceous, hostrock temperatures below $60^{\circ} \mathrm{C}(<2 \mathrm{~km}$; Ksienzyk et al., 2014) make the growth of discrete illite significantly more difficult and I/S becomes the datable mineral in the youngest faults. Accordingly, KI values for sample $\mathrm{KN} 1$ suggest early diagenetic conditions $\left(<100^{\circ} \mathrm{C}\right)$. The difficulty to grow illite at such low temperatures might also explain the relative scarcity of dated fault activity at this time.

Three samples (BG-115, BG-116, BT) show considerable contamination with high-grade muscovite from the host rock. Their $10 \AA$ illite/muscovite peaks are composite peaks of this inherited muscovite and fault-grown illite or I/S. Their KI values cannot be considered to be representative of either generation of illite/muscovite but are generally low, being dominated by the sharp peaks of the inherited host-rock muscovite. Indeed, the smectiterich nature of the fault-grown I/S in the samples BG-115 and $\mathrm{BG}-116$ rather suggests temperatures below $100^{\circ} \mathrm{C}$, which are in agreement with the general cooling path of the host rocks (Fig. 8).

In summary, KI values from fault rocks are not always representative of temperatures in the host rock. Temperature estimates can be much too high when the samples are contaminated with muscovite from metamorphic or magmatic host rocks, or when faults experienced additional heating due to friction or hydrothermal fluid convection. However, fault gouge seems to form at much higher temperatures and greater depths than what is generally assumed. This observation is not limited to western Norway; based on polytype composition (the presence of authigenic $2 \mathrm{M}_{1}$ illite) and illite crystallinity, a number of studies have documented illite crystallisation in fault gouges under temperature conditions corresponding to at least the anchizone $\left(>200^{\circ} \mathrm{C}\right)$, for example in northern Norway (Davids et al., 2013; Torgersen et al., 2014), Finland (Viola et al., 2013), the Alps (Zwingmann \& Mancktelow, 2004; Zwingmann et al., 2010b; Surace et al., 2011; Pleuger et al., 2012), Argentina (Löbens et al., 2011; Bense et al., 2014) and South Korea (Zwingmann et al., 2011). It appears that the temperature range at which fault gouges form might need to be re-evaluated.

\section{Conclusions}

Tectonic activity onshore western Norway occurred episodically since the Devonian. Four periods of fault movement have been identified: the earliest faultrelated illite crystallisation in the Late Devonian-Early Carboniferous (>340 Ma), significant fault activity in the latest Carboniferous-Mid Permian (305-270 Ma) and Late Triassic-Early Jurassic (215-180 Ma) and local fault reactivation in the Early Cretaceous (120-110 $\mathrm{Ma}$ ). Onshore and offshore tectonics are clearly linked. Widespread Early Permian faulting in onshore West Norway supports an Early Permian rift initiation in the North Sea at roughly the same time as the onset of rift-related volcanism in the central North Sea and the Oslo Rift. The significant Late Triassic-Early Jurassic episode of onshore fault activity is either significantly less pronounced in offshore areas or has so far been poorly documented; recent studies based on offshore seismic data point toward the latter. Early Cretaceous fault activity onshore seems to lag somewhat behind Late Jurassic (Phase 2) rifting in the North Sea or might be correlated with Early Cretaceous North Atlantic rifting.

Acknowledgements. We gratefully acknowledge funding from the University of Bergen and VISTA, a joint scholarship program from the Academy of Science and Letters and Statoil. We thank H. Hauso (Statens Vegvesen), T. Kirkjeby (Statens Vegvesen) and J.B.A. Rasmussen $(\mathrm{UiB})$ for samples from Espelandstunnelen, Knappetunnelen and Grønnevikstunnelen. The student research assistants (Hiwis) of the $\mathrm{K}$-Ar laboratory at the University of Göttingen are thanked for their help with the sample preparation and analyses. We thank the editor, T. Slagstad; and the reviewers E. Torgersen and L. Staisch are thanked for thorough and constructive reviews.

\section{References}

Andersen, T.B. 1998: Extensional tectonics in the Caledonides of southern Norway, an overview. Tectonophysics 285, 333-351. http://dx.doi.org/10.1016/S0040-1951(97)00277-1.

Andersen, T.B. \& Jamtveit, B. 1990: Uplift of deep crust during orogenic extensional collapse: a modal based on field studies in the Sogn-Sunnfjord region of western Norway. Tectonics 9, 10971112. http://dx.doi.org/10.1029/TC009i005p01097.

Andersen, T.B., Torsvik, T.H., Eide, E.A., Osmundsen, P.T. \& Faleide, J.I. 1999: Permian and Mesozoic extensional faulting within the Caledonides of central south Norway. Journal of the Geological Society of London 156, 1073-1080. http://dx.doi.org/10.1144/ gsjgs.156.6.1073.

Andriessen, P.A.M. \& Bos, A. 1986: Post-Caledonian thermal evolution and crustal uplift in the Eidfjord area, western Norway. Norsk Geologisk Tidsskrift 66, 243-250.

Austrheim, H. 1987: Eclogitization of lower crustal granulites by fluid migration through shear zones. Earth and Planetary Science Letters 81, 221-232. http://dx.doi.org/10.1016/0012821X(87)90158-0.

Badley, M.E., Price, J.D., Rambech Dahl, C. \& Agdestein, T. 1988: The structural evolution of the northern Viking Graben and its bearing upon extensional modes of basin formation. Journal of 
the Geological Society of London 145, 455-472. http://dx.doi. org/10.1144/gsjgs.145.3.0455.

Bailey, S.W., Hurley, P.M., Fairbairn, H.W. \& Pinson, W.H., Jr. 1962: $\mathrm{K}-\mathrm{Ar}$ dating of sedimentary illite polytypes. Geological Society of America Bulletin 73, 1167-1170. http://dx.doi.org/10.1130/00167606(1962)73[1167:KDOSIP]2.0.CO;2.

Bell, R.E., Jackson, C.A.-L., Whipp, P.S. \& Clements, B. 2014: Strain migration during multiphase extension: observations from the northern North Sea. Tectonics 33, 1936-1963. http://dx.doi. org/10.1002/2014TC003551.

Bense, F.A., Wemmer, K., Löbens, S. \& Siegesmund, S. 2014: Fault gouge analyses: $\mathrm{K}-\mathrm{Ar}$ illite dating, clay mineralogy and tectonic significance - a study from the Sierras Pampeanas, Argentina. International Journal of Earth Sciences 103, 189-218. http:/ dx.doi.org/10.1007/s00531-013-0956-7.

Bingen, B. \& Solli, A. 2009: Geochronology of magmatism in the Caledonian and Sveconorwegian belts of Baltica: synopsis for detrital zircon provenance studies. Norwegian Journal of Geology $89,267-290$.

Bingen, B., Davis, W.S. \& Austrheim, H. 2001: Zircon U-Pb geochronology in the Bergen arc eclogites and their Proterozoic protoliths, and implications for the pre-Scandian evolution of the Caledonides in western Norway. Geological Society of America Bulletin 113, 640-649. http://dx.doi.org/10.1130/00167606(2001)113<0640:ZUPGIT>2.0.CO;2.

Boundy, T.M., Essene, E.J., Hall, C.M., Austrheim, H. \& Halliday, A.N. 1996: Rapid exhumation of lower crust during continentcontinent collision and late extension: Evidence from $40 \mathrm{Ar} / 39 \mathrm{Ar}$ incremental heating of hornblendes and muscovites, Caledonian orogen, western Norway. Geological Society of America Bulletin 108, 1425-1437. http://dx.doi.org/10.1130/00167606(1996)108<1425:REOLCD > 2.3.CO;2.

Brockamp, O. \& Clauer, N. 2013: Hydrothermal and unexpected diagenetic alteration in Permian shales of the Lodève epigenetic U-deposit of southern France, traced by K-Ar illite and K-feldspar dating. Chemical Geology 357, 18-28. http://dx.doi.org/10.1016/j. chemgeo.2013.08.009.

Chester, F.M., Friedman, M. \& Logan, J.M. 1985: Foliated cataclasites. Tectonophysics 111, 139-146. http://dx.doi. org/10.1016/0040-1951(85)90071-X.

Choo, C.O. \& Chang, T.W. 2000: Characteristics of clay minerals in gouges of the Dongrae Fault, southeastern Korea, and implications for fault activity. Clays and Clay Minerals 48, 204-212. http:/ dx.doi.org/10.1346/CCMN.2000.0480206.

Clauer, N. 2013: The $\mathrm{K}-\mathrm{Ar}$ and 40Ar/39Ar methods revisited for dating fine-grained K-bearing clay minerals. Chemical Geology 354, 163-185. http://dx.doi.org/10.1016/j. chemgeo.2013.05.030.

Cocks, L.R.M. \& Torsvik, T.H. 2006: European geography in a global context from the Vendian to the end of the Palaeozoic. In Gee, D.G. \& Stephenson, R.A. (eds.): European Lithosphere Dynamics, Geological Society of London Memoirs 32, pp. 83-95. http:// dx.doi.org/10.1144/gsl.mem.2006.032.01.05.

Corfu, F. \& Dahlgren, S. 2008: Perovskite U-Pb ages and the $\mathrm{Pb}$ isotopic composition of alkaline volcanism initiating the PermoCarboniferous Oslo Rift. Earth and Planetary Science Letters 265, 256-269. http://dx.doi.org/10.1016/j.epsl.2007.10.019.

Dahlgren, S., Corfu, F. \& Heaman, L.M. 1996: U-Pb Isotopic Time Constraints, and $\mathrm{Hf}$ and $\mathrm{Pb}$ Source Characteristics of the Larvik Plutonic Complex, Oslo Paleorift. Geodynamic and Geochemical Implications for the Rift Evolution. Sixth V.M. Goldschmidt Conference, 31 March-4 April, Heidelberg, Germany, Journal of Conference Abstracts 1, p. 120.

Dahlgren, S., Corfu, F. \& Heaman, L. 1998: Datering av plutoner og pegmatitter i Larvik pluton-kompleks, sydlige Oslo Graben, ved hjelp av $\mathrm{U}-\mathrm{Pb}$ isotoper i zirkon og baddeleyitt. Norsk Bergverksmuseum Skrift 14, 32-39.
Davids, C., Wemmer, K., Zwingmann, H., Kohlmann, F., Jacobs, J. \& Bergh, S.G. 2013: K-Ar illite and apatite fission track constraints on brittle faulting and the evolution of the northern Norwegian passive margin. Tectonophysics 608, 196-211. http://dx.doi. org/10.1016/j.tecto.2013.09.035.

Deng, C., Fossen, H., Gawthorpe, R.L., Rotevatn, A., Jackson, C.A.-L. \& Fazli Khani, H. in review: Structural evolution during multiphase rifting: Oseberg area, northern North Sea. Journal of Structural Geology.

Doré, A.G., Lundin, E.R., Jensen, L.N., Birkeland, Ø., Eliassen, P.E. \& Fichler, C. 1999: Principal tectonic events in the evolution of the northwest European Atlantic margin. In Fleet, A.J. \& Boldy, S.A.R. (eds.): Petroleum Geology of Northwest Europe: Proceedings of the 5th Conference, Geological Society of London, Petroleum Geology Conference series 5, pp. 41-61. http://dx.doi. org/10.1144/0050041.

Dunlap, W.J. \& Fossen, H. 1998: Early Paleozoic orogenic collapse, tectonic stability, and late Paleozoic continental rifting revealed though thermochronology of K-feldspars, southern Norway. Tectonics 17, 604-620. http://dx.doi. org/10.1029/98TC01603.

Duvall, A.R., Clark, M.K., van der Pluijm, B.A. \& Li, C. 2011: Direct dating of Eocene reverse faulting in northeastern Tibet using Ar-dating of fault clays and low-temperature thermochronometry. Earth and Planetary Science Letters 304, 520-526. http://dx.doi. org/10.1016/j.eps1.2011.02.028.

Eagar, R.M.C. 1994: Non-marine bivalve assemblage in the Asker Group, Oslo Graben and its correlation with a late Pennsylvanian assemblage from North America. Journal of the Geological Society of London 151, 669-680. http://dx.doi.org/10.1144/ gsjgs. 151.4.0669.

Eberl, D.D. \& Velde, B. 1989: Beyond the Kubler Index. Clay Minerals 24, 571-577. http://dx.doi.org/10.1180/ claymin.1989.024.4.01.

Eide, E.A., Torsvik, T.H. \& Andersen, T.B. 1997: Absolute dating of brittle fault movements: Late Permian and late Jurassic extensional fault breccias in western Norway. Terra Nova 9, 135-139. http:// dx.doi.org/10.1046/j.1365-3121.1997.d01-21.x.

Fossen, H. 1988: The Ulriken Gneiss Complex and the Rundemanen Formation: a basement-cover relationship in the Bergen Arcs, West Norway. Norges geologiske undersøkelse Bulletin 412, 67-86.

Fossen, H. 1993: Structural evolution of the Bergsdalen Nappes, Southwest Norway. Norges geologiske undersøkelse Bulletin 424, 23-49.

Fossen, H. 1998: Advances in understanding the post-Caledonian structural evolution of the Bergen area, West Norway. Norsk Geologisk Tidsskrift 78, 33-46.

Fossen, H. 2000: Extensional tectonics in the Caledonides: Synorogenic or postorogenic? Tectonics 19, 213-224. http:// dx.doi.org/10.1029/1999TC900066.

Fossen, H. 2010: Extensional tectonics in the North Atlantic Caledonides: a regional view. In Law, R.D., Butler, R.W.H., Holdsworth, R.E., Krabbendam, M. \& Strachan, R.A. (eds.): Continental Tectonics and Mountain Building: The Legacy of Peach and Horne, Geological Society of London Special Publications 335, pp. 767-793. http://dx.doi.org/10.1144/ sp335.31.

Fossen, H. \& Dallmeyer, R.D. 1998: 40Ar/39Ar muscovite dates from the nappe region of southwestern Norway: dating extensional deformation in the Scandinavian Caledonides. Tectonophysics 285, 119-133. http://dx.doi.org/10.1016/S00401951(97)00187-X.

Fossen, H. \& Dunlap, W.J. 1998: Timing and kinematics of Caledonian thrusting and extensional collapse, southern Norway: evidence from 40Ar/39Ar thermochronology. Journal of Structural Geology 20, 765-781. http://dx.doi.org/10.1016/S01918141(98)00007-8. 
Fossen, H. \& Dunlap, W.J. 1999: On the age and tectonic significance of Permo-Triassic dikes in the Bergen-Sunnhordland region, southwestern Norway. Norsk Geologisk Tidsskrift 79, 169-178. http://dx.doi.org/10.1080/002919699433807.

Fossen, H. \& Dunlap, W.J. 2006: Age constraints on the late Caledonian (Scandian) deformation in the Major Bergen Arc, SW Norway. Norwegian Journal of Geology 86, 59-70.

Fossen, H. \& Hurich, C.A. 2005: The Hardangerfjord Shear Zone in SW Norway and the North Sea: a large-scale low-angle shear zone in the Caledonian crust. Journal of the Geological Society of London 162, 675-687. http://dx.doi.org/10.1144/0016-764904-136.

Fossen, H. \& Ragnhildstveit, J. 2008: Berggrunnskart Bergen 1115 I, scale 1:50,000, Norges geologiske undersøkelse.

Fossen, H., Mangerud, G., Hesthammer, J., Bugge, T. \& Gabrielsen, R.H. 1997: The Bjorøy Formation: a newly discovered occurrence of Jurassic sediments in the Bergen Arc System. Norsk Geologisk Tidsskrift 77, 269-287.

Fossen, H., Gabrielsen, R.H., Faleide, J.I. \& Hurich, C.A. 2014: Crustal stretching in the Scandinavian Caledonides as revealed by deep seismic data. Geology 42, 791-794. http://dx.doi. org/10.1130/G35842.1.

Fossen, H., Khani, H.F., Faleide, J.I., Ksienzyk, A.K. \& Dunlap, W.J. 2016: Post-Caledonian extension in the West Norway-northern North Sea region: the role of structural inheritance. In Childs, C., Holdsworth, R.E., Jackson, C.A.-L., Manzocchi, T., Walsh, J.J. \& Yielding, G. (eds.): The Geometry and Growth of Normal Faults, Geological Society of London Special Publications 439. http:// dx.doi.org/10.1144/sp439.6.

Færseth, R.B. 1996: Interaction of Permo-Triassic and Jurassic extensional fault-blocks during the development of the northern North Sea. Journal of the Geological Society of London 153, 931944. http://dx.doi.org/10.1144/gsjgs.153.6.0931.

Færseth, R.B., Macintyre, R.M. \& Naterstad, J. 1976: Mesozoic alkaline dykes in the Sunnhordland region, western Norway: ages, geochemistry and regional significance. Lithos 9, 331-345. http:// dx.doi.org/10.1016/0024-4937(76)90023-2.

Færseth, R.B., Gabrielsen, R.H. \& Hurich, C.A. 1995: Influence of basement in structuring of the North Sea basin, offshore southwest Norway. Norsk Geologisk Tidsskrift 75, 105-119.

Gabrielsen, R.H., Færseth, R.B., Steel, R.J., Idil, S. \& Kløvjan, O.S. 1990: Architectural styles of basin fill in the northern Viking Graben. In Blundell, D.J. \& Gibbs, A.D. (eds.): Tectonic Evolution of the North Sea Rifts, Clarendon Press, Oxford, pp. 158-179.

Gee, D.G., Fossen, H., Henriksen, N. \& Higgins, A.K. 2008: From the Early Paleozoic Platforms of Baltica and Laurentia to the Caledonide Orogen of Scandinavia and Greenland. Episodes 31, 44-51.

Gee, D.G., Juhlin, C., Pascal, C. \& Robinson, P. 2010: Collisional Orogeny in the Scandinavian Caledonides (COSC). Geologiska Föreningen i Stockholm Förhandlingar 132, 29-44. http://dx.doi. org/10.1080/11035891003759188.

Grathoff, G.H. \& Moore, D.M. 1996: Illite polytype quantification using Wildfire $\subset$ calculated X-ray diffraction patterns. Clays and Clay Minerals 44, 835-842. http://dx.doi.org/10.1346/ CCMN.1996.0440615.

Grathoff, G.H., Moore, D.M., Hay, R.L. \& Wemmer, K. 1998: Illite Polytype Quantification and K/Ar Dating of Paleozoic Shales: A Technique to Quantify Diagenetic and Detrital Illite. In Schieber, J., Zimmerle, W. \& Sethi, P.S. (eds.): Shales and Mudstones II Petrography, Petrophysics, Geochemistry, and Economic Geology, E. Schweizerbart'sche Verlagsbuchhandlung, Stuttgart, Germany, pp. 161-175.

Grathoff, G.H., Moore, D.M., Hay, R.L. \& Wemmer, K. 2001: Origin of illite in the lower Paleozoic of the Illinois basin: Evidence for brine migrations. Geological Society of America Bulletin 113, 1092-1104. http://dx.doi.org/10.1130/00167606(2001)113<1092:OOITL>2.0.CO;2.
Haines, S.H. \& van der Pluijm, B.A. 2008: Clay quantification and Ar-Ar dating of synthetic and natural gouge: Application to the Miocene Sierrra Mazatán detachment fault, Sonora, Mexico. Journal of Structural Geology 30, 525-538. http://dx.doi. org/10.1016/j.jsg.2007.11.012.

Haines, S.H. \& van der Pluijm, B.A. 2010: Dating the detachment fault system of the Ruby Mountains, Nevada: Significance for the kinematics of low-angle normal faults. Tectonics 29, TC4028. http://dx.doi.org/10.1029/2009TC002552.

Harrison, T.M., Célérier, J., Aikman, A.B., Hermann, J. \& Heizler, M.T. 2009: Diffusion of 40Ar in muscovite. Geochimica et Cosmochimica Acta 73, 1039-1051. http://dx.doi.org/10.1016/j. gca.2008.09.038.

Heeremans, M. \& Faleide, J.I. 2004: Late Carboniferous-Permian tectonics and magmatic activity in the Skagerrak, Kattegat and the North Sea. In Wilson, M., Neumann, E.-R., Davies, G.R., Timmerman, M.J., Heeremans, M. \& Larsen, B.T. (eds.): PermoCarboniferous Magmatism and Rifting in Europe, Geological Society of London Special Publications 223, pp. 157-176. http:// dx.doi.org/10.1144/gsl.sp.2004.223.01.07.

Heeremans, M., Timmerman, M.J., Kirstein, L.A. \& Faleide, J.I. 2004: New constraints on the timing of late Carboniferous-early Permian volcanism in the central North Sea. In Wilson, M., Neumann, E.-R., Davies, G.R., Timmerman, M.J., Heeremans, M. \& Larsen, B.T. (eds.): Permo-Carboniferous Magmatism and Rifting in Europe, Geological Society of London Special Publications 223, pp. 177-194. http://dx.doi.org/10.1144/gsl. sp.2004.223.01.08.

Hower, J., Hurley, P.M., Pinson, W.H. \& Fairbairn, H.W. 1963: The dependence of $\mathrm{K}-\mathrm{Ar}$ age on the mineralogy of various particle size ranges in a shale. Geochimica et Cosmochimica Acta 27, 405-410. http://dx.doi.org/10.1016/0016-7037(63)90080-2.

Hower, J., Eslinger, E.V., Hower, M.E. \& Perry, E.A. 1976: Mechanism of burial metamorphism of argillaceous sediment: 1. Mineralogical and chemical evidence. Geological Society of America Bulletin 87, 725-737. http://dx.doi.org/10.1130/00167606(1976)87<725:MOBMOA>2.0.CO;2.

Hunziker, J.C., Frey, M., Clauer, N., Dallmeyer, R.D., Friedrichsen, H., Flehmig, W., Hochstrasser, K., Roggwiler, P. \& Schwander, H. 1986: The evolution of illite to muscovite: mineralogical and isotopic data from the Glarus Alps, Switzerland. Contributions to Mineralogy and Petrology 92, 157-180. http://dx.doi.org/10.1007/ BF00375291.

Jennings, S. \& Thompson, G.R. 1986: Diagenesis of Plio-Pleistocene sediments of the Colorado River delta, southern California. Journal of Sedimentary Petrology 56, 89-98.

Johannessen, K.C., Kohlmann, F., Ksienzyk, A.K., Dunkl, I. \& Jacobs, J. 2013: Tectonic evolution of the SW Norwegian passive margin based on low-temperature thermochronology from the innermost Hardangerfjord area. Norwegian Journal of Geology 93, 243-260.

Ksienzyk, A.K. 2012: From mountains to basins: geochronological case studies from southwestern Norway, Western Australia and East Antarctica. PhD thesis, University of Bergen, 162 pp.

Ksienzyk, A.K., Dunk1, I., Jacobs, J., Fossen, H. \& Kohlmann, F. 2014: From orogen to passive margin: constraints from fission track and (U-Th)/He analyses on Mesozoic uplift and fault reactivation in SW Norway. In Corfu, F., Gasser, D. \& Chew, D.M. (eds.): New Perspectives on the Caledonides of Scandinavia and Related Areas, Geological Society of London Special Publications 390, pp. 679-702. http://dx.doi.org/10.1144/sp390.27.

Kübler, B. 1964: Les argiles indicateurs de métamorphisme. Revue de l'institute Francais du Petrolé 19, 1093-1112.

Kübler, B. 1967: La cristallinité de l'illite et les zones tout à fait supérieures du métamorphisme. In Schaer, J.P. (ed.): Colloque sur les étages tectoniques, À la Baconnière, Neuchâtel, Switzerland, pp. 105-122. 
Kühn, A., Glodny, J., Austrheim, H. \& Råheim, A. 2002: The Caledonian tectono-metamorphic evolution of the Lindås Nappe: Constraints from $\mathrm{U}-\mathrm{Pb}, \mathrm{Sm}-\mathrm{Nd}$ and $\mathrm{Rb}-\mathrm{Sr}$ ages of granitoid dykes. Norsk Geologisk Tidsskrift 82, 45-57.

Larsen, Ø., Fossen, H., Langeland, K. \& Pedersen, R.-B. 2003: Kinematics and timing of polyphase post-Caledonian deformation in the Bergen area, SW Norway. Norwegian Journal of Geology 83, $149-165$.

Larsen, B.T., Olaussen, S., Sundvoll, B. \& Heeremans, M. 2008: The Permo-Carboniferous Oslo Rift through six stages and 65 million years. Episodes 31, 52-58.

Leighton, C.A. 2007: The thermotectonic development of southern Norway: constraints from low-temperature thermochronology. $\mathrm{PhD}$ thesis, Imperial College London, $296 \mathrm{pp}$.

Lepercq, J.-Y. \& Gaulier, J.-M. 1996: Two-stage rifting in the North Viking Graben area (North Sea): inferences from a new threedimensional subsidence analysis. Marine and Petroleum Geology 13, 129-148. http://dx.doi.org/10.1016/0264-8172(95)00031-3.

Löbens, S., Bense, F.A., Wemmer, K., Dunkl, I., Costa, C.H., Layer, P. \& Siegesmund, S. 2011: Exhumation and uplift of the Sierras Pampeanas: preliminary implications from $\mathrm{K}-\mathrm{Ar}$ fault gouge dating and low-T thermochronology in the Sierra de Comechingones (Argentina). International Journal of Earth Sciences 100, 671-694. http://dx.doi.org/10.1007/s00531-010-0608-0.

Lovera, O.M., Richter, F.M. \& Harrison, T.M. 1989: The 40Ar/39Ar Thermochronometry for Slowly Cooled Samples Having a Distribution of Diffusion Domain Sizes. Journal of Geophysical Research 94, 17917-17935. http://dx.doi.org/10.1029/JB094iB12p17917.

Lyons, J.B. \& Snellenburg, J. 1971: Dating faults. Geological Society of America Bulletin 82, 1749-1752. http://dx.doi.org/10.1130/00167606(1971)82[1749:DF]2.0.CO;2.

Løvlie, R. \& Mitchell, J.G. 1982: Complete remagnetization of some Permian dykes from western Norway induced during burial/uplift. Physics of the Earth and Planetary Interiors 30, 415-421. http:// dx.doi.org/10.1016/0031-9201(82)90051-6.

McDougall, I. \& Harrison, T.M. 1999: Geochronology and Thermochronology by the 40Ar/39Ar Method. Oxford University Press, New York, 269 pp.

Merriman, R.J. \& Frey, M. 1999: Patterns of very low-grade metamorphism in metapelitic rocks. In Frey, M. \& Robinson, D. (eds.): LowGrade Metamorphism, Blackwell Science, Oxford, pp. 61-107.

Merriman, R.J. \& Peacor, D.R. 1999: Very low-grade metapelites: mineralogy, microfabrics and measuring reaction progress. In Frey, M. \& Robinson, D. (eds.): Low-Grade Metamorphism, Blackwell Science, Oxford, pp. 10-60.

Milnes, A.G., Wennberg, O.P., Skår, Ø. \& Koestler, A.G. 1997: Contraction, extension and timing in the South Norwegian Caledonides: the Sognefjord transect. In Burg, J.-P. \& Ford, M. (eds.): Orogeny Through Time, Geological Society of London Special Publications 121, pp. 123-148. http://dx.doi.org/10.1144/ gsl.sp.1997.121.01.06.

Neumann, E.-R., Olsen, K.H., Baldridge, W.S. \& Sundvoll, B. 1992: The Oslo Rift: a review. Tectonophysics 208, 1-18. http://dx.doi. org/10.1016/0040-1951(92)90333-2.

Neumann, E.-R., Wilson, M., Heeremans, M., Spencer, E.A., Obst, K., Timmerman, M.J. \& Kirstein, L. 2004: Carboniferous-Permian rifting and magmatism in southern Scandinavia, the North Sea and northern Germany: a review. In Wilson, M., Neumann, E.-R., Davies, G.R., Timmerman, M.J., Heeremans, M. \& Larsen, B.T. (eds.): Permo-Carboniferous Magmatism and Rifting in Europe, Geological Society of London Special Publications 223, pp. 11-40. http://dx.doi.org/10.1144/gsl.sp.2004.223.01.02.

Odinsen, T., Reemst, P., van der Beek, P., Faleide, J.I. \& Gabrielsen, R.H. 2000: Permo-Triassic and Jurassic extension in the northern North Sea: results from tectonostratigraphic forward modelling. In Nøttvedt, A. (ed.): Dynamics of the Norwegian Margin, Geological Society of London Special Publications 167, pp. 83-103. http:/ dx.doi.org/10.1144/gsl.sp.2000.167.01.05.
Olaussen, S., Larsen, B.T. \& Steel, R. 1994: The Upper CarboniferousPermian Oslo Rift; Basin Ffill in Relation to Tectonic Development. In Embry, A.F., Beauchamp, B. \& Glass, D.J. (eds.): Pangea: Global Environments and Resources, Canadian Society of Petroleum Geologists Memoir 17, pp. 175-197.

Pascal, C. \& Cloetingh, S.A.P.L. 2002: Rifting in heterogeneous lithosphere: Inferences from numerical modeling of the northern North Sea and the Oslo Graben. Tectonics 21, 1060. http://dx.doi. org/10.1029/2001TC901044

Pedersen, L.E., Heaman, L.M. \& Holm, P.M. 1995: Further constraints on the temporal evolution of the Oslo Rift from precise $\mathrm{U}-\mathrm{Pb}$ zircon dating in the Siljan-Skrim area. Lithos 34, 301-315. http:// dx.doi.org/10.1016/0024-4937(94)00014-S.

Pevear, D.R. 1992: Illite age analysis, a new tool for basin thermal history analysis. In Kharaka, Y.K. \& Maest, A.S. (eds.): Proceedings of the 7th International Symposium on Water-Rock Interaction, Balkema, Rotterdam, pp. 1251-1254.

Pevear, D.R. 1999: Illite and hydrocarbon exploration. Proceedings of the National Academy of Sciences of the United States of America 96, 3440-3446. http://dx.doi.org/10.1073/pnas.96.7.3440.

Pleuger, J., Mancktelow, N., Zwingmann, H. \& Manser, M. 2012: KAr dating of synkinematic clay gouges from Neoalpine faults of the Central, Western and Eastern Alps. Tectonophysics 550-553, 1-16. http://dx.doi.org/10.1016/j.tecto.2012.05.001.

Pluijm, B.A. van der, Hall, C.M., Vrolijk, P.J., Pevear, D.R. \& Covey, M.C. 2001: The dating of shallow faults in the Earth's crust. Nature 412, 172-175. http://dx.doi.org/10.1038/35084053.

Ragnhildstveit, J. \& Helliksen, D. 1997: Geologisk kart over Norge, berggrunsskart Bergen, scale 1:250,000, Norges geologiske undersøkelse.

Rahl, J.M., Haines, S.H. \& van der Pluijm, B.A. 2011: Links between orogenic wedge deformation and erosional exhumation: Evidence from illite age analysis of fault rock and detrital thermochronology of syn-tectonic conglomerates in the Spanish Pyrenees. Earth and Planetary Science Letters 307, 180-190. http://dx.doi. org/10.1016/j.eps1.2011.04.036.

Rasmussen, J.B.A. 2013: Detaljstudie av skyvekontakt mellom Vesle Bergensboge og Øygardskomplekset med tunneltekniske aspekt. MSc thesis, University of Bergen, 98 pp.

Redfield, T.F., Torsvik, T.H., Andriessen, P.A.M. \& Gabrielsen, R.H. 2004: Mesozoic and Cenozoic tectonics of the Møre Trøndelag Fault Complex, central Norway: constraints from new apatite fission track data. Physics and Chemistry of the Earth 29, 673-682. http://dx.doi.org/10.1016/j.pce.2004.03.005.

Redfield, T.F., Braathen, A., Gabrielsen, R.H., Osmundsen, P.T., Torsvik, T.H. \& Andriessen, P.A.M. 2005: Late Mesozoic to early Cenozoic components of vertical separation across the MøreTrøndelag Fault Complex, Norway. Tectonophysics 395, 233-249. http://dx.doi.org/10.1016/j.tecto.2004.09.012.

Refvem, M.A. 2016: Spatial and temporal evolution of fault arrays on the northren Utsira High, northern North Sea. MSc thesis, University of Bergen, $75 \mathrm{pp}$.

Roberts, A.M., Yielding, G., Kusznir, N.J., Walker, I.M. \& DornLopez, D. 1995: Quantitative analysis of Triassic extension in the northern Viking Graben. Journal of the Geological Society of London 152, 15-26. http://dx.doi.org/10.1144/gsjgs.152.1.0015.

Rohrman, M., van der Beek, P., Andriessen, P. \& Cloetingh, S. 1995: Meso-Cenozoic morphotectonic evolution of southern Norway: Neogene domal uplift inferred from apatite fission track thermochronology. Tectonics 14, 704-718. http://dx.doi. org/10.1029/95TC00088

Sasseville, C., Tremblay, A., Clauer, N. \& Liewig, N. 2008: K-Ar age constraints on the evolution of polydeformed fold-thrust belts: The case of the Northern Appalachians (southern Quebec). Journal of Geodynamics 45, 99-119. http://dx.doi.org/10.1016/j. jog.2007.07.004.

Sasseville, C., Clauer, N. \& Tremblay, A. 2012: Timing of fault reactivation in the upper crust of the St. Lawrence rift system, 
Canada, by $\mathrm{K}-\mathrm{Ar}$ dating of illite-rich fault rocks. Canadian Journal of Earth Sciences 49, 637-652. http://dx.doi.org/10.1139/ e2012-008.

Sibson, R.H. 1977: Fault rocks and fault mechanisms. Journal of the Geological Society of London 133, 191-213. http://dx.doi. org/10.1144/gsjgs.133.3.0191.

Siebel, W., Hann, H.P., Danišík, M., Shang, C.K., Berthold, C., Rohrmüller, J., Wemmer, K. \& Evans, N.J. 2010: Age constraints on faulting and fault reactivation: a multi-chronological approach. International Journal of Earth Sciences 99, 1187-1197. http:// dx.doi.org/10.1007/s00531-009-0474-9.

Smit, M.A., Scherer, E.E., Bröcker, M. \& van Roermund, H.L.M. 2010: Timing of eclogite facies metamorphism in the southernmost Scandinavian Caledonides by $\mathrm{Lu}-\mathrm{Hf}$ and $\mathrm{Sm}-\mathrm{Nd}$ geochronology. Contributions to Mineralogy and Petrology 159, 521-539. http:// dx.doi.org/10.1007/s00410-009-0440-3.

Snoke, A.W. \& Tullis, J. 1998: An overview of fault rocks. In Snoke, A.W., Tullis, J. \& Todd, V.R. (eds.): Fault-related Rocks - A Photographic Atlas, Princeton University Press, Princeton, pp. 3-18.

Solum, J.G., van der Pluijm, B.A. \& Peacor, D.R. 2005: Neocrystallization, farbrics and age of clay minerals from an exposure of the Moab Fault, Utah. Journal of Structural Geology 27, 1563-1576. http://dx.doi.org/10.1016/j.jsg.2005.05.002.

Środoń, J. \& Eberl, D.D. 1984: Illite. In Bailey, S.W. (ed.): Micas, Reviews in Mineralogy 13, Mineralogical Society of America, pp. 495-544.

Steel, R. \& Ryseth, A. 1990: The Triassic - Early Jurassic succession in the northern North Sea: megasequence stratigraphy and intraTriassic tectonics. In Hardman, R.F.P. \& Brooks, J. (eds.): Tectonic Events Responsible for Britain's Oil and Gas Reserves, Geological Society of London Special Publications 55, pp. 139-168. http:// dx.doi.org/10.1144/gsl.sp.1990.055.01.07.

Steiger, R.H. \& Jäger, E. 1977: Subcommission on Geochronology: Convention on the Use of Decay Constants in Geo- and Cosmochronology. Earth and Planetary Science Letters 36, 359362. http://dx.doi.org/10.1016/0012-821X(77)90060-7.

Stemmerik, L., Ineson, J.R. \& Mitchell, J.G. 2000: Stratigraphy of the Rotliegend Group in the Danish part of the Northern Permian Basin, North Sea. Journal of the Geological Society London 157, 1127-1136. http://dx.doi.org/10.1144/jgs.157.6.1127.

Streule, M.J., Strachan, R.A., Searle, M.P. \& Law, R.D. 2010: Comparing Tibet-Himalayan and Caledonian crustal architecture, evolution and mountain building processes. In Law, R.D., Butler, R.W.H., Holdsworth, R.E., Krabbendam, M. \& Strachan, R.A. (eds.): Continental Tectonics and Mountain Building: The Legacy of Peach and Horne, Geological Society of London Special Publications 335, pp. 207-232. http://dx.doi.org/10.1144/sp335.10.

Sundvoll, B. \& Larsen, B.T. 1990: Rb-Sr isotope systematics in the magmatic rocks of the Oslo Rift. Norges geologiske undersøkelse Bulletin 418, 27-46.

Sundvoll, B. \& Larsen, B.T. 1993: Rb-Sr and Sm-Nd relationshipts in dyke and sill intrusions in the Oslo Rift and related areas. Norges geologiske undersøkelse Bulletin 425, 25-42.

Sundvoll, B., Neumann, E.-R., Larsen, B.T. \& Tuen, E. 1990: Age relations among Oslo Rift magmatic rocks: implications for tectonic and magmatic modelling. Tectonophysics 178, 67-87. http://dx.doi.org/10.1016/0040-1951(90)90460-P.

Surace, I.R., Clauer, N., Thélin, P. \& Pfeifer, H.-R. 2011: Structural analysis, clay mineralogy and $\mathrm{K}-\mathrm{Ar}$ dating of fault gouges from Centovalli Line (Central Alps) for reconstrcution of their recent activity. Tectonophysics 510, 80-93. http://dx.doi. org/10.1016/i.tecto.2011.06.019.

Torgersen, E., Viola, G., Zwingmann, H. \& Harris, C. 2014: Structural and temporal evolution of a reactivated brittle-ductile fault - Part II: Timing of fault initiation and reactivation by $\mathrm{K}-$ Ar dating of synkinematic illite/muscovite. Earth and Planetary Science Letters 407, 221-233. http://dx.doi.org/10.1016/i. epsl.2014.09.031.

Torgersen, E., Viola, G., Zwingmann, H. \& Henderson, I.H.C. 2015 : Inclined $\mathrm{K}-\mathrm{Ar}$ illite age spectra in brittle fault gouges: effects of fault reativation and wall-rock contamination. Terra Nova 27, 106-113. http://dx.doi.org/10.1111/ter.12136.

Torsvik, T.H., Sturt, B.A., Swensson, E., Andersen, T.B. \& Dewey, J.F. 1992: Palaeomagnetic dating of fault rocks: evidence for Permian and Mesozoic movements and brittle deformation along the extensional Dalsfjord Fault, western Norway. Geophysical Journal International 109, 565-580. http://dx.doi.org/10.1111/ j.1365-246X.1992.tb00118.x.

Torsvik, T.H., Andersen, T.B., Eide, E.A. \& Walderhaug, H.J. 1997: The age and tectonic significance of dolerite dykes in western Norway. Journal of the Geological Society of London 154, 961973. http://dx.doi.org/10.1144/gsjgs.154.6.0961.

Uysal, I.T., Mutlu, H., Altunel, E., Karabacak, V. \& Golding, S.D. 2006: Clay mineralogical and isotopic $(\mathrm{K}-\mathrm{Ar}, \delta 18 \mathrm{O}, \delta \mathrm{D})$ constraints on the evolution of the North Anatolian Fault Zone, Turkey. Earth and Planetary Science Letters 243, 181-194. http:// dx.doi.org/10.1016/j.eps1.2005.12.025.

Valle, P., Færseth, R.B. \& Fossen, H. 2002: Devonian-Triassic brittle deformation based on dyke geometry and fault kinematics in the Sunnhordland region, SW Norway. Norsk Geologisk Tidsskrift 82, 3-17.

van Roermund, H.L.M. 2009: Recent progress in Scandian ultrahighpressure metamorphism in the northernmost domain of the Western Gneiss Complex, SW Norway: continental subduction down to 180-200 km depth. Journal of the Geological Society of London 166, 739-751.

van Roermund, H.L.M. \& Drury, M.R. 1998: Ultra-high pressure $(\mathrm{P}>6 \mathrm{GPa})$ garnet peridotites in Western Norway: exhumation of mantle rocks from $>185 \mathrm{~km}$ depth. Terra Nova 10, 295-301. http://dx.doi.org/10.1046/j.1365-3121.1998.00213.x.

Viola, G., Zwingmann, H., Mattila, J. \& Käpyaho, A. 2013: K-Ar illite age constraints on the Proterozoic formation and reactivation history of a brittle fault in Fennoscandia. Terra Nova 25, 236-244. http://dx.doi.org/10.1111/ter.12031.

Viola, G., Scheiber, T., Fredin, O., Zwingmann, H., Margreth, A. \& Knies, J. 2016: Deconvoluting complex structural histories archived in brittle fault zones. Nature Communications 7, Article Number 13448. doi: 10.1038/ncomms 13448.

Vrolijk, P. \& van der Pluijm, B.A. 1999: Clay gouge. Journal of Structural Geology 21, 1039-1048. http://dx.doi.org/10.1016/ S0191-8141(99)00103-0.

Walsh, E.O., Hacker, B.R., Gans, P.B., Grove, M. \& Gehrels, G. 2007: Protolith ages and exhumation histories of (ultra)high-pressure rocks across the Western Gneiss Region, Norway. Geological Society of America Bulletin 119, 289-301. http://dx.doi. org/10.1130/B25817.1.

Wemmer, K. 1991: K/Ar-Altersdatierungsmöglichkeiten für retrograde Deformationsprozesse im spröden und duktilen Bereich - Beispiele aus der KTB-Vorbohrung (Oberpfalz) und dem Bereich der Insubrischen Linie (N-Italien). $\mathrm{PhD}$ thesis, University of Göttingen, 61 pp.

Wemmer, K. \& Ahrendt, H. 1997: Comparative K-Ar and Rb-Sr age determinations of retrograde processes on rocks from the KTB deep drilling project. Geologische Rundschau 86, S272-S285. http://dx.doi.org/10.1007/PL00014660.

Wennberg, O.P. \& Milnes, A.G. 1994: Interpretation of kinematic indicators along the northeastern margin of the Bergen Arc System: a preliminary field study. Norsk Geologisk Tidsskrift 74, 166-173.

Wennberg, O.P., Milnes, A.G. \& Winsvold, I. 1998: The northern Bergen Arc Shear Zone - an oblique-lateral ramp in the Devonian extensional detachment system of western Norway. Norsk Geologisk Tidsskrift 78, 169-184.

Yan, Y., van der Pluijm, B.A. \& Peacor, D.R. 2001: Deformation microfabrics of clay gouge, Lewis Thrust, Canada: a case for 
fault weakening from clay transformation. In Holdsworth, R.E., Strachan, R.A., Magloughlin, J.F. \& Knipe, R.J. (eds.): The Nature and Tectonic Significance of Fault Zone Weakening, Geological Society of London Special Publications 186, pp. 103-112. http:// dx.doi.org/10.1144/gsl.sp.2001.186.01.07.

Zwingmann, H. \& Mancktelow, N. 2004: Timing of Alpine fault gouges. Earth and Planetary Science Letters 223, 415-425. http:// dx.doi.org/10.1016/j.eps1.2004.04.041.

Zwingmann, H., Yamada, K. \& Tagami, T. 2010a: Timing of brittle deformation within the Nojima fault zone, Japan. Chemical Geology 275, 176-185. http://dx.doi.org/10.1016/j. chemgeo.2010.05.006.

Zwingmann, H., Mancktelow, N., Antognini, M. \& Lucchini, R. 2010b: Dating of shallow faults: New constraints from the AlpTransit tunnel site (Switzerland). Geology 38, 487-490. http:// dx.doi.org/10.1130/G30785.1.

Zwingmann, H., Han, R. \& Ree, J.-H. 2011: Cretaceous reactivation of the Deokpori Thrust, Taebaeksan Basin, South Korea, constrained by $\mathrm{K}-\mathrm{Ar}$ dating of clayey fault gouge. Tectonics 30, TC5015. http://dx.doi.org/10.1029/2010TC002829. 